\title{
Historical earthquake parameters by geological and seismic site analysis: the 1908 Cerbón earthquake (Spain)
}

\author{
Eugenio Sanz Pérez ${ }^{1}$ Ignacio Menéndez-Pidal ${ }^{1} \cdot$ Rubén Galindo Aires $^{1} \cdot$ \\ Susana López-Querol ${ }^{2} \cdot$ Carlos Pascual-Arribas ${ }^{1}$
}

Received: 2 July 2015/ Accepted: 24 February 2016/Published online: 26 March 2016

(c) The Author(s) 2016. This article is published with open access at Springerlink.com

\begin{abstract}
Seismic catalogues summarize information mainly on recent earthquakes and seismic events, recorded by means of relatively new instruments. Hence, this information, although being of high quality and quantitative value, sometimes is rather incomplete, since historical earthquakes are neglected in many cases. An example is the 1908 Cerbón earthquake (in Spain). This shake caused a good number of effects in the epicentre and surrounding area, triggering a huge landslide among some other effects. A complete geological and seismic site analysis, accompanied by a historical review of testimonies and journals of the time describing this particular earthquake, has been carried out, along with a deep field investigation to identify the mechanism of this landslide and the characteristics of the involved materials. A retrospective pseudo-static numerical simulation has been carried out to calculate the most probable range of peak horizontal accelerations
\end{abstract}

Susana López-Querol

s.lopez-querol@ucl.ac.uk

Eugenio Sanz Pérez

esanz@caminos.upm.es

Ignacio Menéndez-Pidal

ignacio.menendezpidal@upm.es

Rubén Galindo Aires

rubenangel.galindo@upm.es

Carlos Pascual-Arribas

capascual-1@telefonica.net

1 Laboratorio de Geología, Departamento de Ingeniería y Morfología del Terreno, School of Civil Engineering, Technical University of Madrid, C/ Profesor Aranguren s/n, 28040 Madrid, Spain

2 Department of Civil, Environmental and Geomatic Engineering, University College London, Gower Street, London WC1E 6BT, UK during the earthquake. The results demonstrate the moderate relevance of this shake, also allowing us to quantify its objective importance. The presented methodology can be easily extended to some other similar cases, if seismic catalogues are to be completed for future designs accounting for seismic considerations.

Keywords Historical earthquakes - Slope instabilities · Pseudo-static simulation - Superficial earthquakes . Hydrogeological effects of earthquakes

\section{Introduction}

Seismic risk analysis cannot be based only on recorded seismographic information. In most countries, seismic stations have been installed only within the past few years, or they have been scarce enough to accurately allocate local, minor earthquakes that can sometimes can cause damages as severe as strong shakings. For example, in Spain, the institution that records and shows on its website events with magnitudes equal or higher than 2.0 is called IGN (Instituto Geográfico Nacional). Field research on these small earthquakes not only provides additional information, but is also of paramount value to reduce the uncertainties in the allocation of the epicentre, if complemented with available recorded information. Sometimes just field studies, if they are adequately undertaken, could give us an idea of the effects of the seismic loadings caused by an earthquake. The inspection of mobilized faults could also be identified and taken into account for future evaluation of local risks at the same areas.

Field research on historical earthquakes, those that occurred before modern seismology was actually developed, can be even more important. Hundreds of unrecorded 
earthquakes have caused huge amounts of damage and destruction. They are undocumented seismic events for which almost no available information exists, and their effects are also rather unknown. Moreover, sometimes the estimation of regional seismicity levels is not compatible with the local tectonics, and running these estimations is not very useful if local seismic risks are to be properly evaluated. The so-called "surprise earthquakes" demonstrate that sometimes very little is known about latent risks in sites where no seismic activity currently arises. A detailed analysis of the antecedents over a long period of time would be extremely useful and valuable to guide field investigations in such historical seismic sites, as well as to identify recently active faults.

It is well known that earthquakes usually trigger slope instabilities. These failures frequently cause severe material damages (to buildings, structures and infrastructures) as well as casualties (Bird and Bommer 2004). Although plenty of landslides induced at the Iberian Peninsula by ancient earthquakes are well documented, research on this topic is relatively recent both in Spain and Portugal, in comparison with other kinds of slope instabilities (caused by rainfall or erosion, amongst other reasons). In active tectonics studies, recognizing and characterizing slope instabilities is not that frequent: the amount of time from an event to nowadays is sometimes excessively long, and most of the instabilities can be attributed to multiple reasons, making it difficult to establish a unique Paleo-event. Similarly, most of the time, the possible intensity of the event triggering the instability remains rather unknown. In only a very few of the analyses carried out on active faults in the recent times, have earthquakes been identified as their main cause. This is the case of the research on the Sencelles fault, in Mallorca (Silva et al. 2001; Delgado et al. 2013), or the 1504 Carmona earthquake (Vollmert et al. 2011). Using the conclusions derived from these studies, the geological effects of earthquakes in Spain have been evaluated using the macro-seismic scale of Environmental effects of earthquakes ESI-2007 (Michetti 1999; Reichert and Silva 2009; INQUA 2013). This preliminary catalogue includes 32 slope instabilities induced by earthquakes: six big landslides and 23 small movements (Silva et al. 2008). The available information shows that, in most of the cases, the macro-seismic-areas are around $80-100 \mathrm{~km}^{2}$, but significant geological effects (with higher relevance) occur in smaller areas that rarely reach $10 \mathrm{~km}^{2}$, even in those cases associated with intensities higher or equal to VII (Delgado et al. 2013).

The second line of work consisted of the identification and classification of slope instabilities caused by historic or recent events. For cases occurring not long ago, inventories from on-site field investigations have been carried out (Keefer 1984; Rodríguez et al. 1999; Vaz and Zêzere 2011;
Wasowski et al. 2011). The present paper describes a particular example of successful combination of field research, historical analysis and numerical modelling on a landslide that took place during the 1908 Cerbón earthquake (Spain). This earthquake, which occurred from 15 to 16 January 1908, does not appear in the official IGN seimic catalogue. The start point was a report developed by Naranjo (1908), complemented by on-site field research on the effects caused by this earthquake. The site is located at the Iberian Range (Spain), which has been historically considered as a low seismic area. However, on the northwest side of Moncayo Mountain (2315 m), located at the Wealden facies in the Cameros Basin, and linked to the NW-SE direction faults, higher seismic levels are found in the big area located in between Soria and La Rioja (Fig. 1). These faults are also related to the deep water flowing through them and through the Jurassic, carbonate, permeable basement, causing several thermal springs to appear (in Arnedillo, Cervera, Fitero, Grávalos, and so on, MartínEscorza 2005; Auque et al. 1988; Coloma et al. 1966). In this region, small intensity seismic events are relatively frequent (magnitude ranging from 2 to 3). Some medium intensity earthquakes have also taken place, like the 1817 Arnedo and 1929 Turruncún earthquakes, as well as the most recent one, the 1961 Aguilar del rio Alhama earthquake. None of them were high magnitude shakes (magnitude ranging from 5 to 6 ), but their consequences were perceived close to the epicentres, although they were practically unnoticed $200 \mathrm{~km}$ away. It seems strange that the 1908 Cerbón Earthquake is missing in the Spanish seismic catalogue, because it was an important enough event to have been the object of a proper geological analysis by the Instituto Geológico y Minero in 1908. Undoubtedly, during those years, the Spanish seismic network was very incomplete and not very detailed. Moreover, the site was far away from the seismic observatories in operation. As an example, for the 1961 Aguilar del Río Alhama earthquake, around $12 \mathrm{~km}$ away from Cerbón, the error in the location of the epicentre was $10 \mathrm{~km}$. After this earthquake, and aiming to fill the gaps in the seismic information, in 1963, a new observatory based in Logroño (around $60 \mathrm{~km}$ to the NW) was built.

This paper also includes a description of the resulting superficial ruptures and slope instabilities, along with the identification of their triggering mechanism, supported by a retrospective, pseudo-static Finite Element model which simulates the identified landslide, finally obtaining a probable range of peak horizontal accelerations which could have triggered this slope instability. This analysis gives us a quantitative idea on the importance of the seismic event, stressed by the qualitative information and testimonies reported by the local press. Aiming to allocate this particular earthquake in its seismic framework, some 


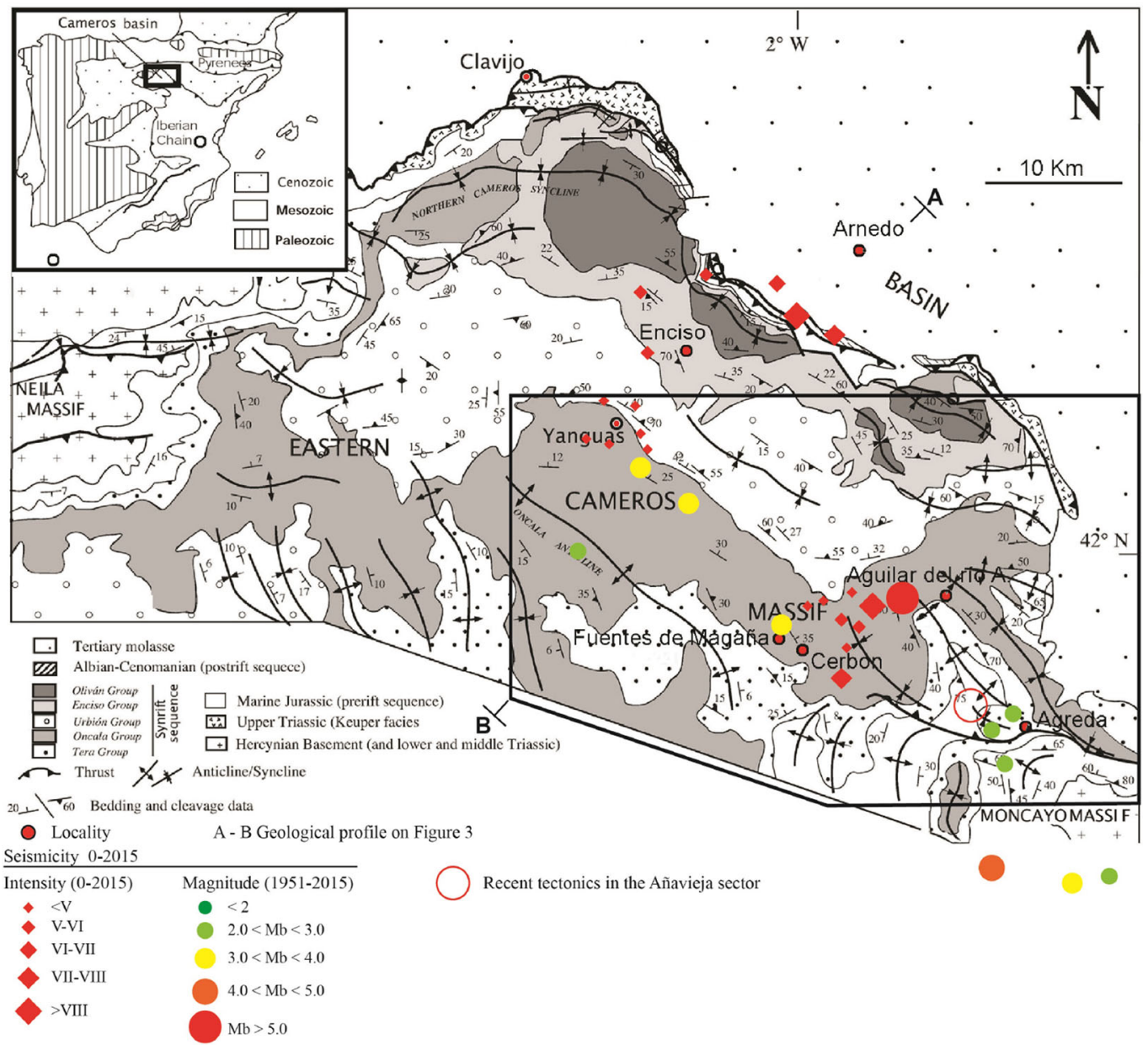

Fig. 1 Geological map through the Sierra de Cameros (adapted from Gil Imaz 2001). Seismicity occurred in the zone until 2015. Intensity and magnitude are indicated. The site and intensity of the historial

other events, which occurred in the same geographical area, previous and subsequent to the 1908 Cerbón earthquake, are also described. Analysis of the observed recent tectonic deformation is also included.

Reconstructing characteristics and conditions of historical earthquakes triggering landslides is not a new activity, and has been a usual procedure since a couple of decades ago (Jibson 1996, 2009). In the present research, an approach to the problem that takes into account the local geological and seismic particularities of the site is presented. In summary, the aim of this research is to demonstrate the suitability of a methodology that could be easily extended and generalised to other similar cases, especially for sites with very little or no existing seismic information, but where evidence of ground deformations after moderate earthquakes arises. In other words, this is a research of seismic events that are not catalogued, either because they were too small to be recorded by seismographs, or because earthquakes are approximate. The circles represent the epicentres, the different colours depicting the magnitude of each event. In the lower square of the figure (SE), the Fig. 2 is allocated

they occurred before these instruments were available. The presented case study can help in identifying and quantifying those earthquakes, in order to complete the available seismic information at a given site, and to include it in the seismic catalogues employed for design purposes.

In summary, the objectives of this research are:

1. To present the analysis of an uncatalogued earthquake in Central Spain, in an area of low seismicity. From information compiled (damage to structures and some ground effects), the authors try to deduce some characteristics of the causative event, such as location, magnitude or maximum intensity.

2. To show that the procedure used (by using the geological study of the landslide induced by the Cerbon earthquake, and its back analysis, as a key element), could improve data for decreasing the incompleteness of the seismic history catalogue. 


\section{Methodology}

Very often, an important limitation in earthquake-induced slope instabilities analyses is the lack of documentation and available information after the seismic event, which, even after a long time, would have allowed accurate identification the amount of mobilized material, along with the proportion that could have been substantially modified by erosion (particularly in soft soils), or by its complete destruction (mainly in the case of rock landslides).

In the present research, a report, developed after the 1908 Cerbón earthquake by Naranjo (1908), has been particularly useful in understanding the main features and extension of a slope failure that took place during the shake. Although this report does not include a proper map, the description of the phenomenon itself has been fundamental, because without this information, the soil displacement would probably have been unnoticed in the field.

Indeed, after consulting the civil governor of Guadalajara (El Avisador Numantino 1908, published on 23 January 1908), this earthquake was investigated in situ by Enrique Naranjo, engineer from the General Corps of Mining Engineers, who reported the main features of the earthquake, as well as its main observed effects on the soil surface. This publication gave us the main clues on the importance and extension of this event, and constitutes the start point for this research.

The employed methodology has been structured according to the following tasks:

- Departing from historical information, an in situ inspection/verification of the site has been carried out, reviewing and improving the mentioned reference, and collecting the maximum possible amount of field data. A thorough and detailed field research has been made, identifying the effects of the earthquake, including the description and interpretation of the observed superficial ruptures.

- Photogeology, prospection and field cartography researches on the superficial rock ruptures have been developed. These observed fractures of the rock, fitting the descriptions provided by Naranjo (1908), are still in good condition, despite more than a century having elapsed after this earthquake. This also applies to the recent quaternary materials, like those affected by the fractures caused by seismic shaking.

- Some other slope instabilities, ruptures and dislocations of the ground, potentially caused by this or some other earthquakes, have been searched. All the local outcrops, $3 \mathrm{~km}$ around, have been checked, primarily along the Canyon of Miraflores (Fig. 4), the most likely location of the epicentre. It is also worth mentioning that almost no quaternary registry appears, but on the contrary, the local stratigraphic series is extremely constant and regular, indicating that all possible tectonic disruption must be clear and evident.

- A detailed stratigraphic column has been made, aiming to accurately identify and clarify the involved materials as well as the competent levels, and to explain their geomechanical characteristics.

- For the loam level, identified in situ as the zone where the sliding took place, typical properties have been estimated, according to the extensive existing bibliography.

- A Finite Element model (using the commercial software PLAXIS 2D) of the main cross section of the landslide has been made. A pseudo-static calculation, obtaining the range of possible horizontal accelerations triggering slope instability, has been developed. The numerically obtained failure pattern has been compared with the available field information. After this analysis, a three-dimensional (3D) simulation was made using FLAC 3D, imposing the same horizontal, pseudostatic acceleration obtained with PLAXIS, to determine the factor of safety and to validate the calculated triggering acceleration with this different numerical approach.

- Unpublished documentation of the few remaining memories of this earthquake has been collected, as well as of some other later events at the same site (particularly, the 1961 Aguilar del rio Alhama earthquake, very close to the one mainly analysed in the present paper), related to the local seismicity.

- Since the effects of the Cerbón earthquake are well reported and known, the Scale of Intensities ESI-2007 has been employed for determining the epicentral local intensity in the site (Michetti 1999).

- A seismic-tectonic site study has been carried out, showing the main strains at macro-structure scale, affecting modern materials at the site. This analysis has been carried out by means of field study and aerial photography, supported by the interpretation of geophysical data (geo-electric profiles) and probes.

In Fig. 3, a flow chart summarising this methodology is presented.

\section{Seismotectonic and seismicity of the studied zone}

\section{Historical seismicity during nineteenth and early twentieth centuries}

Previous to the appearance of recording instruments for seismic events (dated around 1920), it was only possible to undertake incomplete enumeration of seismic events, along with their surrounding circumstances in the particular area 


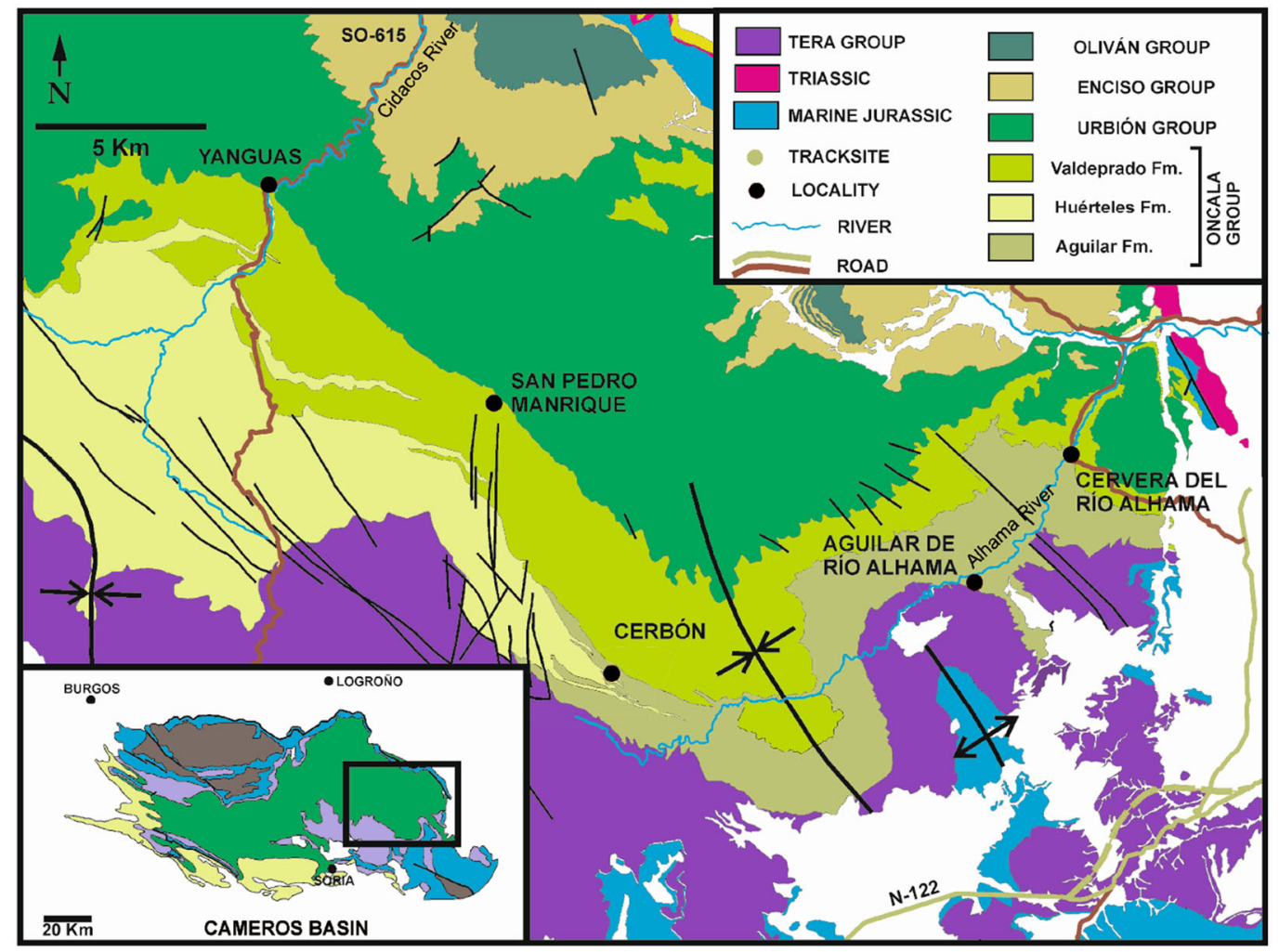

Fig. 2 Geological map of the studied site (after Quijada et al. 2013)

of study. Hence, in the nineteenth century, Palacios (1890), Sánchez Lozano et al. (1894) and some other authors (Egozcue y Cía 1875; Naranjo 1908) enumerate the sites where earthquakes occurred in the provinces of Soria and La Rioja (Spain). The identified earthquakes were: 1817 Préjano and Arnedo Martín-Escorza (2005); 1819, 1845, 1893 Munilla; 1831 Herce; 1846, 1848, 1854, 1857, 1860 Navajún; 1847 Valdelprado; 1875 Arnedillo; and 1884, 1885 Yanguas earthquakes (Figs. 1, 2).

\section{Instrumental era}

The 1908 Cerbón earthquake and some other recent events at the same site: on the night between 15 and 16 January 1908, an earthquake took place in Cerbón, causing evident ground deformations and a big landslide, which is analysed hereinafter in this paper. As previously mentioned, this earthquake is not included in the IGN seismic catalogue. Some other smaller events occurred previously in the same area in 1905 and 1907 (Naranjo 1908). Some seismological stations already existed in Spain, but it seems they were not accurate enough to perceive and record this particular event, and in fact, it is not listed in the seismic data set (Fig. 3).

This earthquake was clearly felt throughout the whole region until at least Trébajo (10 km South from Cerbón,
Fig. 4), as reported in Naranjo (1908). Neither surveys nor any kind of deep analysis were carried out, and thus, the intensity reached in the surrounding towns is unknown. The investigations done in the scope of the present research among elderly inhabitants of the surrounding villages have necessarily been very limited, as there are no survivors (the earthquake occurred more than a century ago). Moreover, the only source of information is through oral tradition, since no written documents on this event, except the aforementioned Naranjo's report, are available.

Memories of having heard news of their ancestors during this earthquake still exist in Cerbón, as well as in Fuentes de Magaña, where furniture moved and many houses cracked while tiles fell down from the roofs. According to these descriptions, this earthquake could be classified in the range of intensities VI-VII. El Avisador Numantino (the local newspaper) described how people panicked. The concern of the population forced the Province Civil Governor to request a recognized specialist in seismicity to write a report, trying to find out the origin of both earthquake and landslide (Fig. 4), as well as the possible relationship between them, and if these events could potentially occur again. The earthquake was noticed by means of a powerful explosion, followed by some smaller other ones, accompanied by vibrations and underground noises coming from the SE, 


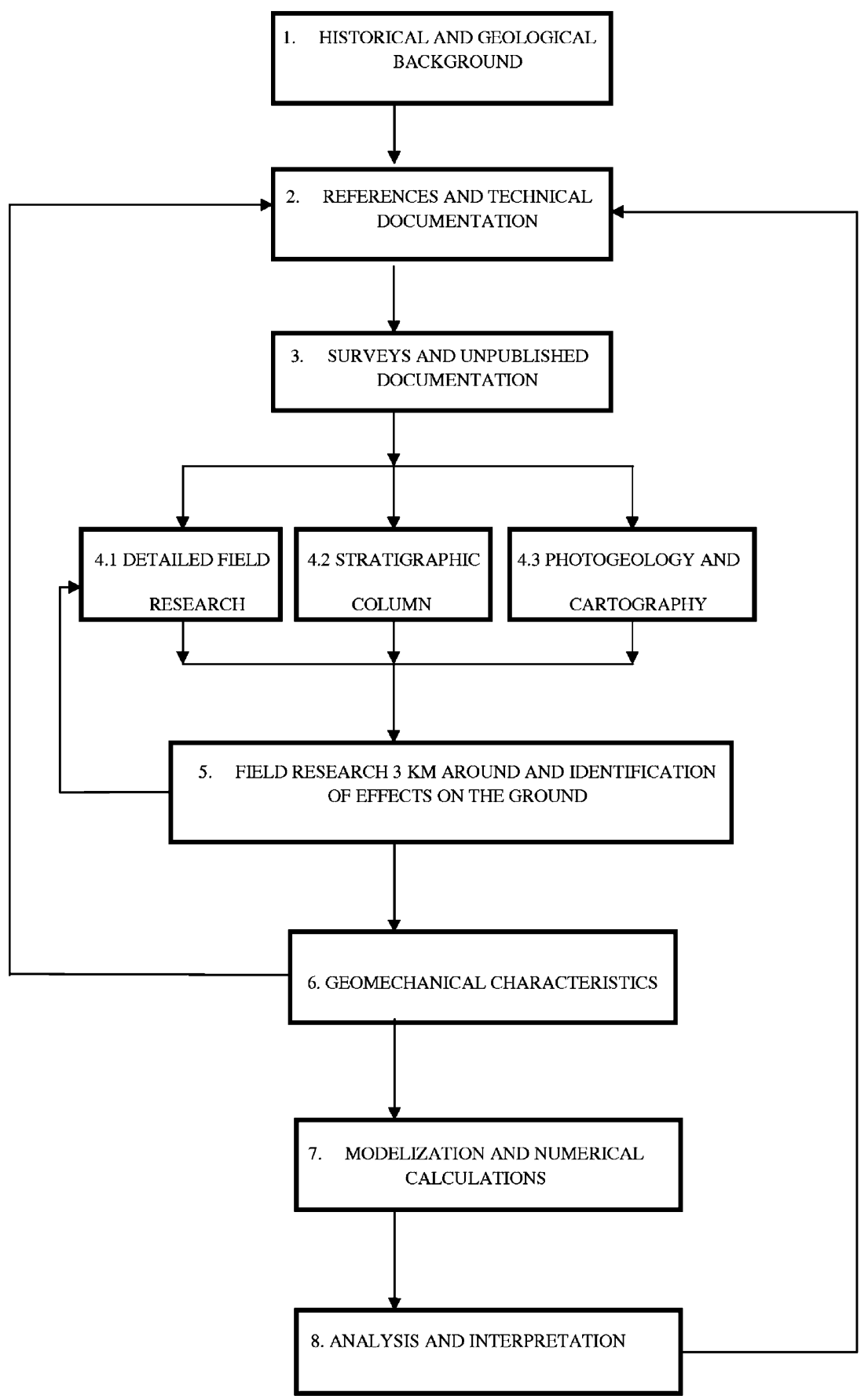

Fig. 3 Flow chart summarising the methodology followed in this research

i.e from the southern area of the Miraflores gorge. Three years before, in 1905, a period of intense quakes took place, causing furniture displacements in the houses. In 1907, several ground shakings and underground noises were perceived. In all three cases, Naranjo describes how the population heard strange noises and undulatory movements at the soil surface. Concerning the environmental effects (Fig. 4), the author highlighted the following:
- Hydrogeological anomalies: the discharge of several surrounding springs suddenly decreased after the earthquake. In the Mountain of Trébajo (Fig. 4), 10 km away from the hypothetical epicentre, a set of six to eight new springs appeared, carrying sulfhydric water at $28^{\circ} \mathrm{C}$, i.e. $16^{\circ}$ higher than the usual temperature of the water in the surrounding springs. These new fountains appeared during or immediately after the earthquake, and some of them flowed for months. 


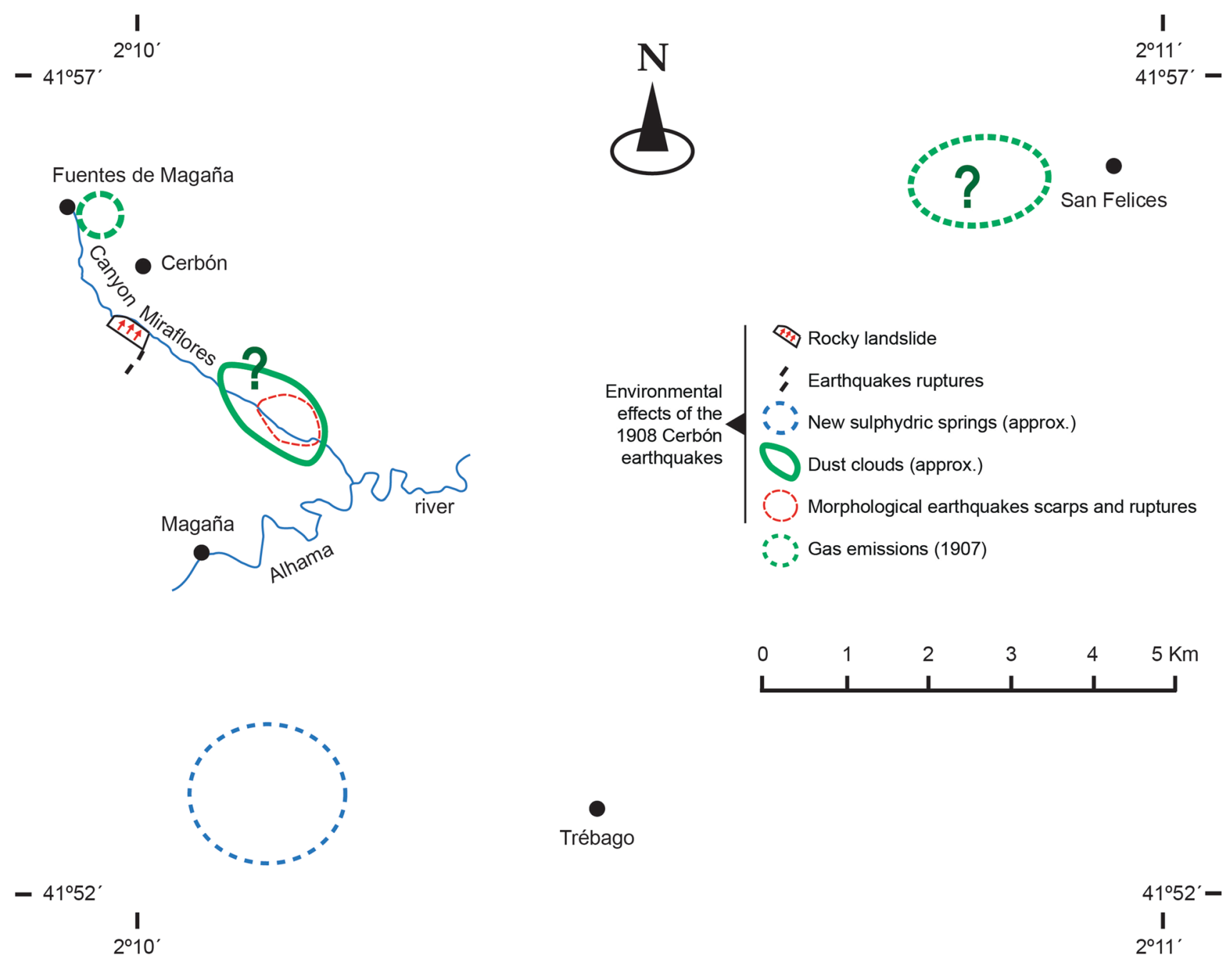

Fig. 4 Map showing the effects of the 1908 Cerbón earthquake

- Dust clouds: a dark cloud was observed over the Miraflores gorge a few hours after hearing the first underground noises.

- Gas emissions: in his report, Naranjo mentioned that, after the 1907 event, a big and short fire took place in Fuentes de Magaña meadows, followed by another one soon after, close to San Felices. This fact could be interpreted as sulphurous or sulfhydric gas emissions.

- Landslides: cracking, fissuring and rocks displacements.

The most important effect, however, was the landslide and ground dislocation that took place $600 \mathrm{~m}$ south of Cerbón, which will be described in detail hereinafter. A local orchard access road was blocked, and a close cote was partially destroyed. Naranjo justified this particular effect as due to the SE-NW orientation of the seismic waves' main direction.

Apart from the 1961 Aguilar del Río Alhama earthquake, several smaller quakes have been reported in this region. Those registered by the IGN are posterior to 1962 , because the Logroño seismic observatory was installed that year. Nowadays, when the Spanish seismic network has been significantly improved, plenty of quakes at this site have been recorded. Thus, it is possible that, in the period of time ranging from 1908 to 1962, other small magnitude, not-registered events occurred, which were, however, noticed by the population of Magaña village every 2 or 3 years.

The most recent recorded quakes in Soria are summarised in Table 1. It is worth noting that the epicentres of some of the quakes were located at Fuentes de Magaña (less than $1 \mathrm{~km}$ away from Cerbón), and, in general, close to this region, demonstrating a significant seismic activity at this site. This fact is also assessed by the available information on earthquakes in Logroño, which not included in this paper, but were also checked.

A magnitude 5.1 earthquake occurred in 18 February 1929. Its epicentre was allocated in Turruncún, close to 
Table 1 Recorded earthquakes at the studied area (IGN)

\begin{tabular}{|c|c|c|c|c|}
\hline Date $(\mathrm{m} / \mathrm{d} / \mathrm{y})$ & Aftershocks & Mw & Intensity & Epicentre \\
\hline 05/03/1847 & - & - & IV-V & Valdeprado \\
\hline 01/01/1886 & - & - & IV & Soria \\
\hline 06/14/1904 & - & - & VI & San Esteban Gormaz \\
\hline $12 / 20 / 1951$ & - & 4.4 & III & Santa Maria de Huerta \\
\hline 05/11/1981 & 5 & 3.0 & - & W Deza \\
\hline 04/09/1987 & 16 & 3.0 & - & NW Beratón \\
\hline 09/24/1987 & 15 & 2.9 & - & NW Santa Cruz de Yanguas \\
\hline 07/18/1989 & - & 2.5 & - & SW Arcos de Jalón \\
\hline 07/04/1993 & 2 & 3.1 & - & E Hinojosa del Campo \\
\hline 12/07/1993 & 5 & 3.0 & - & S Burgo de Osma \\
\hline 04/13/1994 & 8 & 3.7 & $\mathrm{~V}$ & SW Burgo de Osma \\
\hline 04/14/1994 & 20 & 2.7 & - & SE Burgo de Osma \\
\hline 10/13/1994 & 3 & 3.0 & - & S San Pedro de Manrique \\
\hline 09/20/1998 & 4 & 2.9 & II & NW San Pedro de Manrique \\
\hline 03/15/1999 & 1 & 2.8 & - & SW Alconaba \\
\hline 02/02/2001 & 1 & 2.8 & II-III & E Oncala \\
\hline $05 / 31 / 2002$ & - & 2.8 & II-III & SW Burgo de Osma \\
\hline 03/03/2004 & 11 & 2.8 & IV & NW Ágreda \\
\hline 03/04/2004 & 7 & 2.5 & III & W Ágreda \\
\hline 03/06/2004 & - & 2.5 & II-III & SW Ágreda \\
\hline $11 / 24 / 2008$ & 22 & 2.1 & - & Cueva de Ágreda \\
\hline 01/25/2011 & 11 & 2.3 & - & Yanguas \\
\hline 04/12/2011 & 11 & 4.4 & - & Cueva de Ágreda \\
\hline 04/10/2012 & 11 & 2.8 & II-III & San Pedro de Manrique \\
\hline 05/01/2012 & 5 & 2.5 & II & N Fuentes de Magaña \\
\hline 02/03/2013 & 8 & 3.3 & III & SW Beratón \\
\hline
\end{tabular}

Muro de Aguas (La Rioja, Spain) (Rey Pastor 1931). It caused destruction in the surrounding area, but the damage was particularly serious in Turruncún, where the majority of dwellings collapsed, injuring several people, though without any casualties.

The 1961 Aguilar del Río Alhama earthquake had its epicentre in the study area and will be described in greater detail. It occurred on 4 September 1961 at 23:33 h and its epicentre was officially located in the municipality of Aguilar del Rio Alhama. Its magnitude (Mw) was 4.6 according to IGN or 5.8 according to the GSHAP catalogue (Global Seismic Hazard Assessment Program).

\section{Geological settings}

\section{General geological characteristics of the area and stratigraphy in the Cerbon zone}

The area is part of the northern sector of the Aragonese arm of the Iberian Range. In general terms, the stratigraphy comprises a Hercynian basement and a Permo-Triassic tegument, both of which outcrop at the heart of the anticlinorium near Moncayo. Overlying these, there are various Jurassic marine carbonate formations and continental "Purbeck-Weald" facies (Figs. 1, 2, 5, 6). Deposits in these zones are more than $3000 \mathrm{~m}$ thick, though elsewhere in the so-called Cameros Basin, the total thickness of the Wealden facies can exceed $9000 \mathrm{~m}$.

The Oncala Group outcrops in Cerbón Tischer et al. (1966) (Fig. 2). It comprises some $2000 \mathrm{~m}$ of clastic and carbonate sediments. In the eastern part of the Cameros Basin, this group is differentiated into a number of formations/alloformations, which form part of the sedimentary fill sequence III of the Basin (Mas et al. 2004, 2011). Given the lithological characteristics of the sediments (Clemente 2010; Quijada et al. 2013), in this sub-basin, we can differentiate three large formations: Fm. Huérteles, Fm. Aguilar and Fm. Valdeprado. The first of these is characterized by a predominance of clastic sediments, and the other two by a preponderance of carbonate sediments. They are considered to date from the Middle Berriasian (Mas et al. 2004; Clemente 2010).

Given that the stratigraphic succession is apparently quite similar throughout, a $30-\mathrm{m}$ sample of the column from the study area was logged in detail (Fig. 6) in order to 


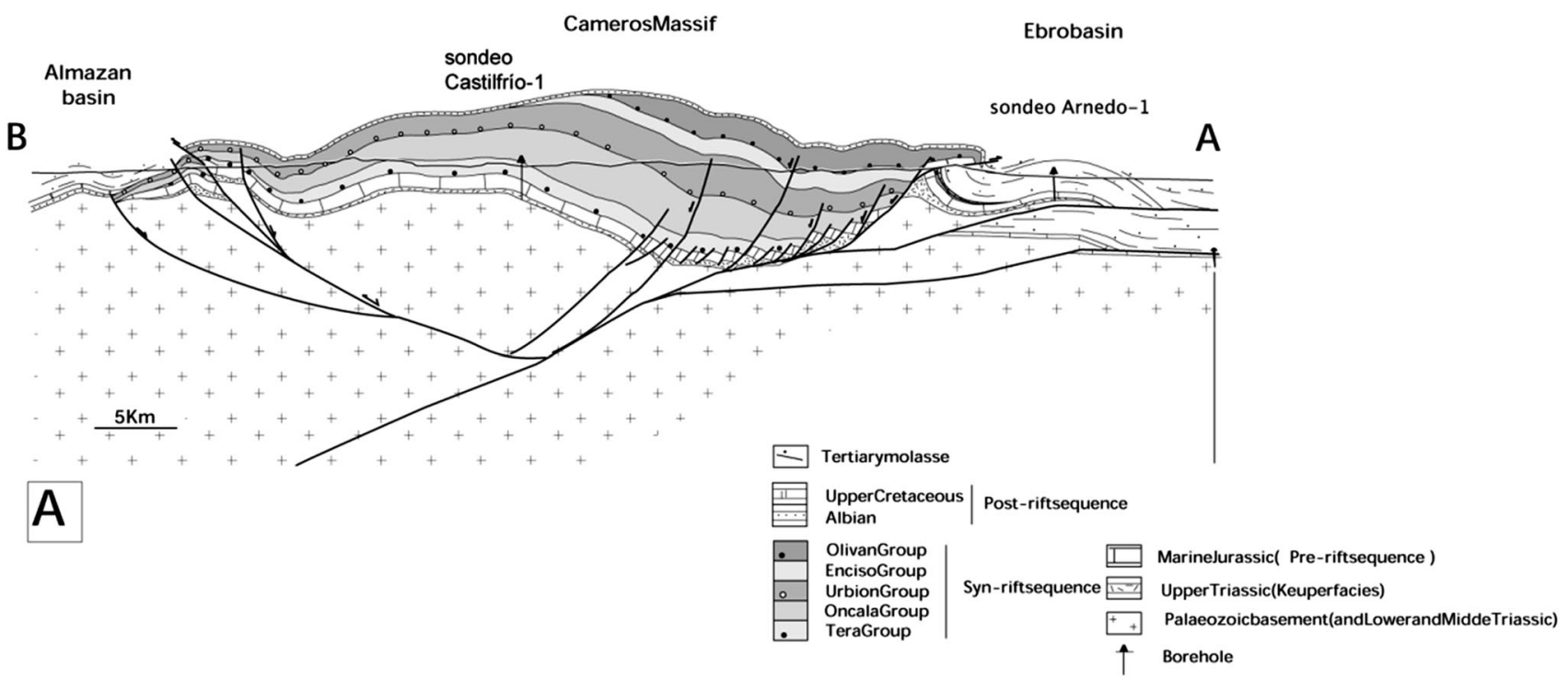

Fig. 5 Geological cross section through the Sierra de Cameros, see Fig. 1

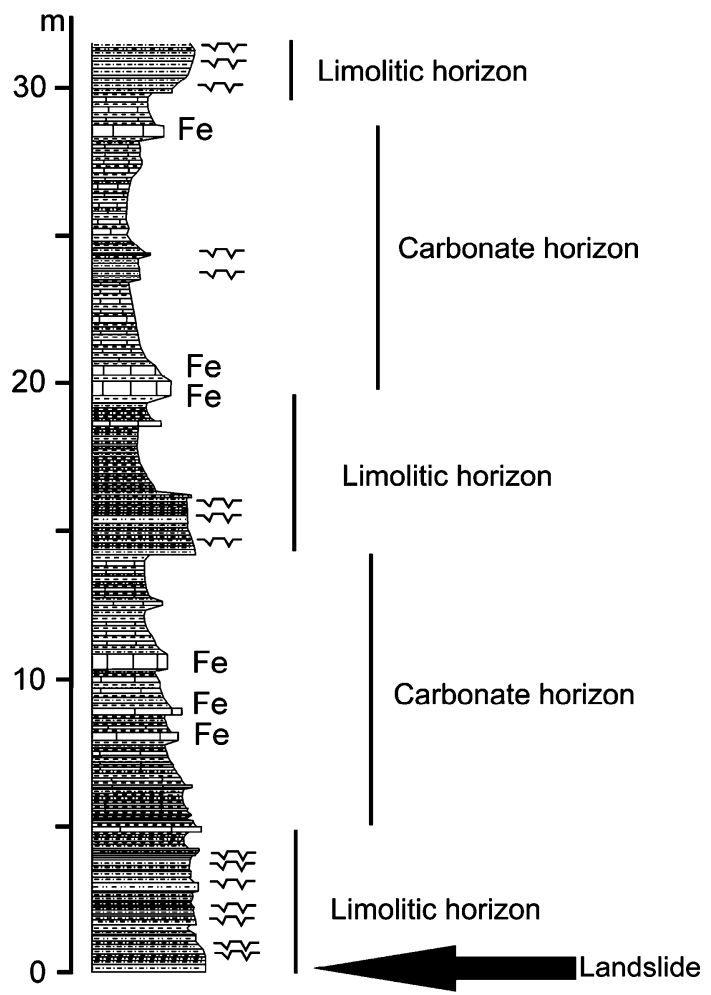

Fig. 6 Detailed stratigraphic column showing the horizons involved in the landslide and the localization of the detached gypsiferous marls. The arrow shows the clayey-loamy gypsiferous level through which the sliding took place

get a precise understanding of the materials involved and the incompetent levels, to be able to explain the geomechanical characteristics of the landslide. As can be seen from Fig. 6, the stratigraphy consists of alternating limolitic and carbonate horizons. The landslide affects a packet
20-30 m thick, which contains two horizons that have very different mechanical behaviours from each other. The upper one, around $15 \mathrm{~m}$ thick, is competent, while the clayey layer below, 5-6 m thick, is not.

The base that slipped consists of whitish and grey sandy limolites, in beds $10-20 \mathrm{~cm}$ thick that are grouped in horizons of $1-1.5 \mathrm{~m}$. This is followed by a carbonate horizon of quite crumbly pale limestones and calcareous clays (with sulphates), which are weathered at the surface, giving white or yellowish soil. This soft and slippery layer outcrops along the eastern edge of the landslide in the Arroyo de Miraflores and in its headwaters, as can be seen in the geological section in Fig. 7. The clayey base measures $4.5-6 \mathrm{~m}$. The remainder of the series comprises limonites and sanstones.

\section{Geological structure}

The study zone lies on the southern edge of the Cameros Basin, on its border with the rest of the Iberian Range, and close to the eastern border of the basin with the Tertiary Ebro Basin (Fig. 1). The most significant structure, formed in the Tertiary compressive stage, is the Cameros nappe, which runs NE-SE; it continues NE in the nappe of the Sierra de la Demanda, and SE in the Sierra del Moncayo (Gil Imaz 2001).

The structure of the epicentre zone is apparently simple, corresponding to the eastern flank of the Valdeprado syncline, where the stratigraphic series is composed of well-stratified fine beds trending NW-SE and inclined towards the NE at a constant angle with a $20^{\circ}-40^{\circ}$ dip. Some of the stratigraphy traces, also trending NW-SE, are illustrated in Fig. 8.

Aerial pictures highlight that there are few fractures of any significance. These are also represented in Fig. 8, 

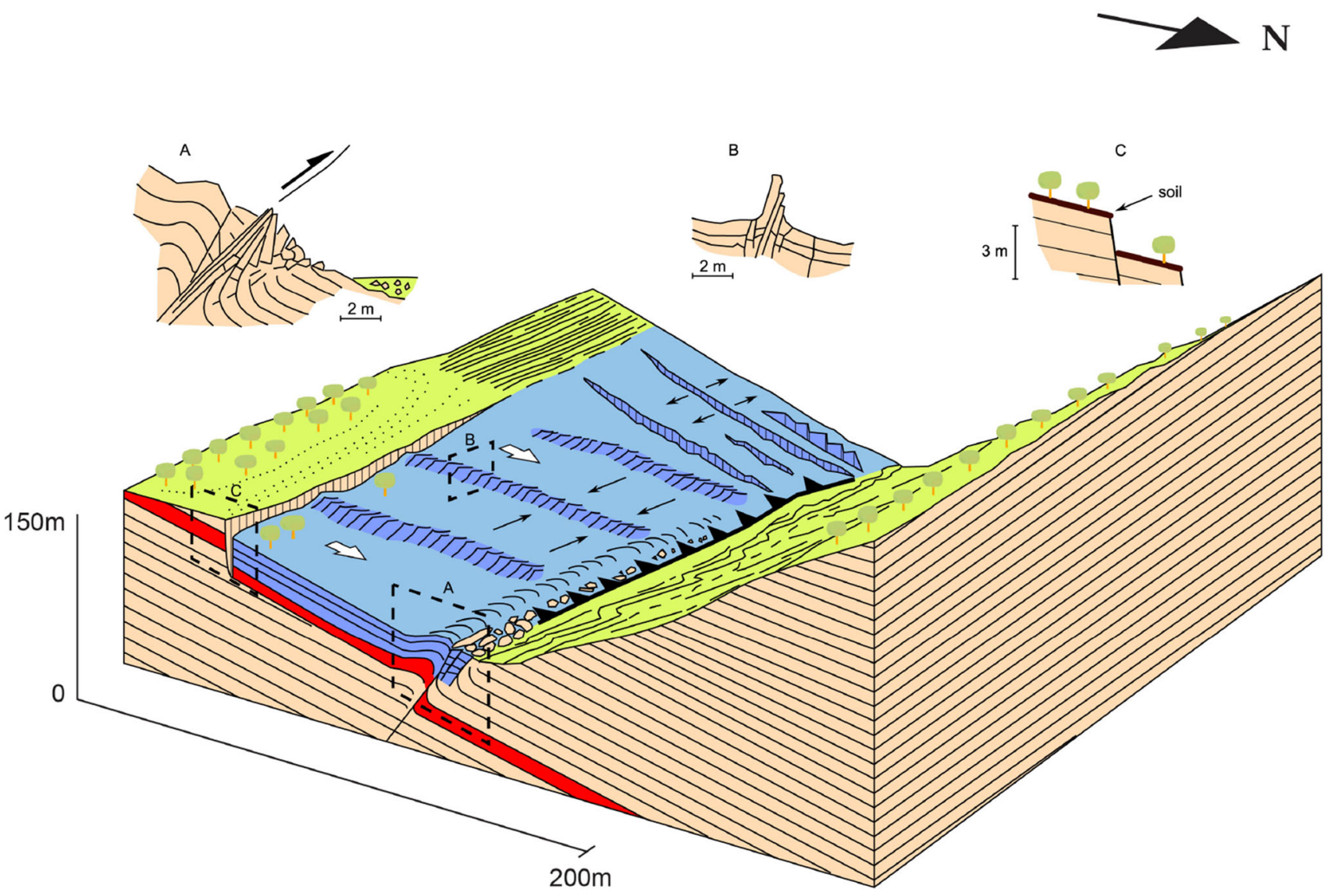

Fig. 7 Land deformation associated with Cerbón earthquake (1908). a Scarp of the lower fissure formed during the earthquake and the parallel micro-anticline. b Traction fractures. $\mathbf{c}$ Escarpment of the upper crack

where they can be seen to have an almost $\mathrm{N}-\mathrm{S}$ direction; the intense faulting in the Miraflores ravine stands out.

The seismic reflection surveys done for oil prospecting in this region show that there are some notable faults, such as the one that runs $\mathrm{N}-\mathrm{S}$ to the east of Magaña and Fuentes de Magaña. Its manifestation at the ground surface may correspond to those indicated in Fig. 8.

\section{Recent tectonics in the Añavieja sector}

The absence of significant Tertiary and Quaternary deposits in the epicentral zone-which might have been deformed by tectonic activity-makes it difficult to identify recent tectonics. As a result, the hydrographic catchment of the river Alhama has undergone continuous and intense erosion since the Miocene, and so little evidence remains of Quaternary sediments, except the Holocene alluvial of the drainage network. However, if we consider the broader study zone, there is a Tertiary-Quaternary microcatchment in the river Añamaza, around $15 \mathrm{~km} \mathrm{SE}$ of Cerbón, which contains clear evidence of recent tectonics. It lies on the southern edge of the Cameros Basin, and several authors consider that the Moncayo nappe must pass through it.
Recent deformations are considered as those that have occurred after the Middle Miocene, the period when the main overthrusts on the northern edge of Cameros-Demanda massif ceased to act, after which they have behaved as the passive edge over which the Neogene materials (post Middle-Miocene) of the Duero and Ebro Basins lap.

\section{Ground effects attributable to the Cerbón earthquake of 1908}

Ruptures appear on the stratification surface of some layers of grey calcareous limonites and sandy limestones in the Berriasian Huérteles Alloformation (described above), which outcrop on the lower slope of the right bank of the Miraflores ravine, $600 \mathrm{~m}$ south of Cerbón and around 1200 $\mathrm{m}$ from the Fuentes de Magaña. All the beds in the area are oriented $\mathrm{N}-135^{\circ} \mathrm{E}$ and dip between $20^{\circ}$ and $30^{\circ}$, a dip angle that coincides with the slope angle of the right bank. On the opposite slope, the stratification is counterslope and completely stable (pictures in Fig. 9). The moved and disturbed zone occupies almost all of this structural relief of the left bank, where the stratification coincides with the 


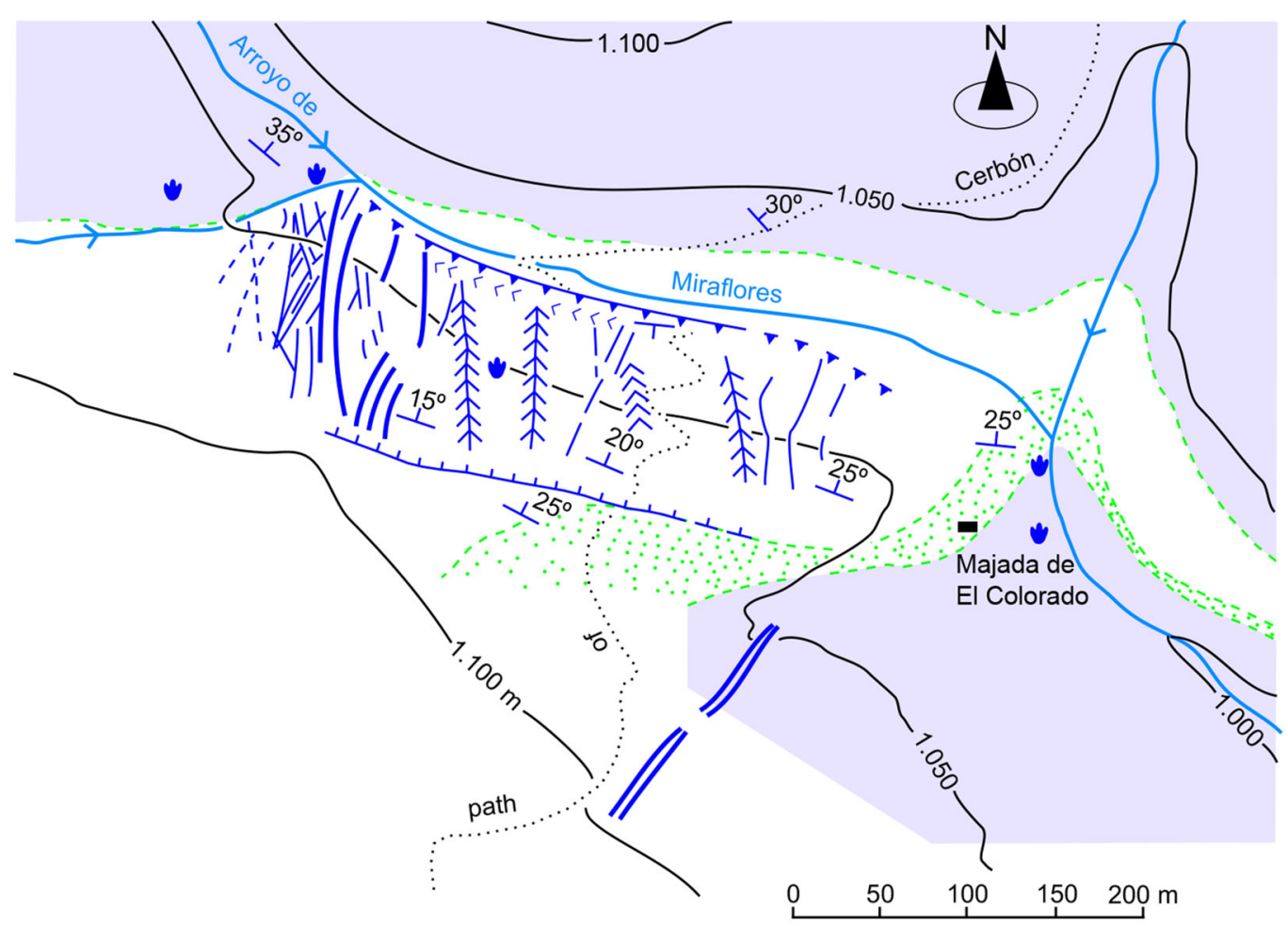

\section{Earthquakes ruptures and folds}
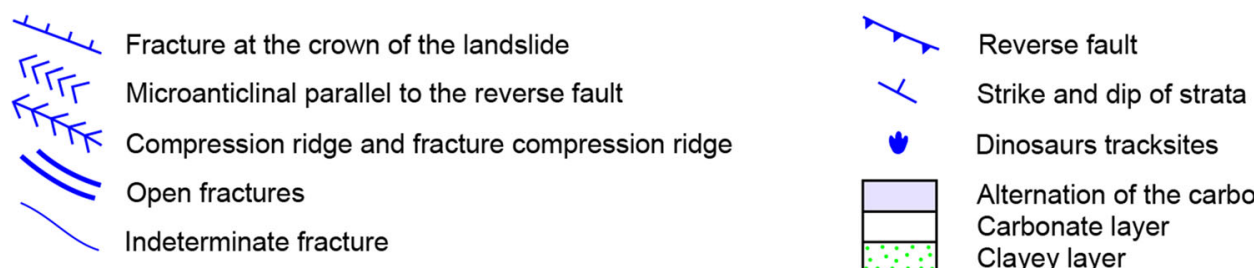

v Dinosaurs tracksites

Alternation of the carbonate and clayey horizonts Carbonate layer Clayey layer

Alternation of the carbonate and clayey horizonts

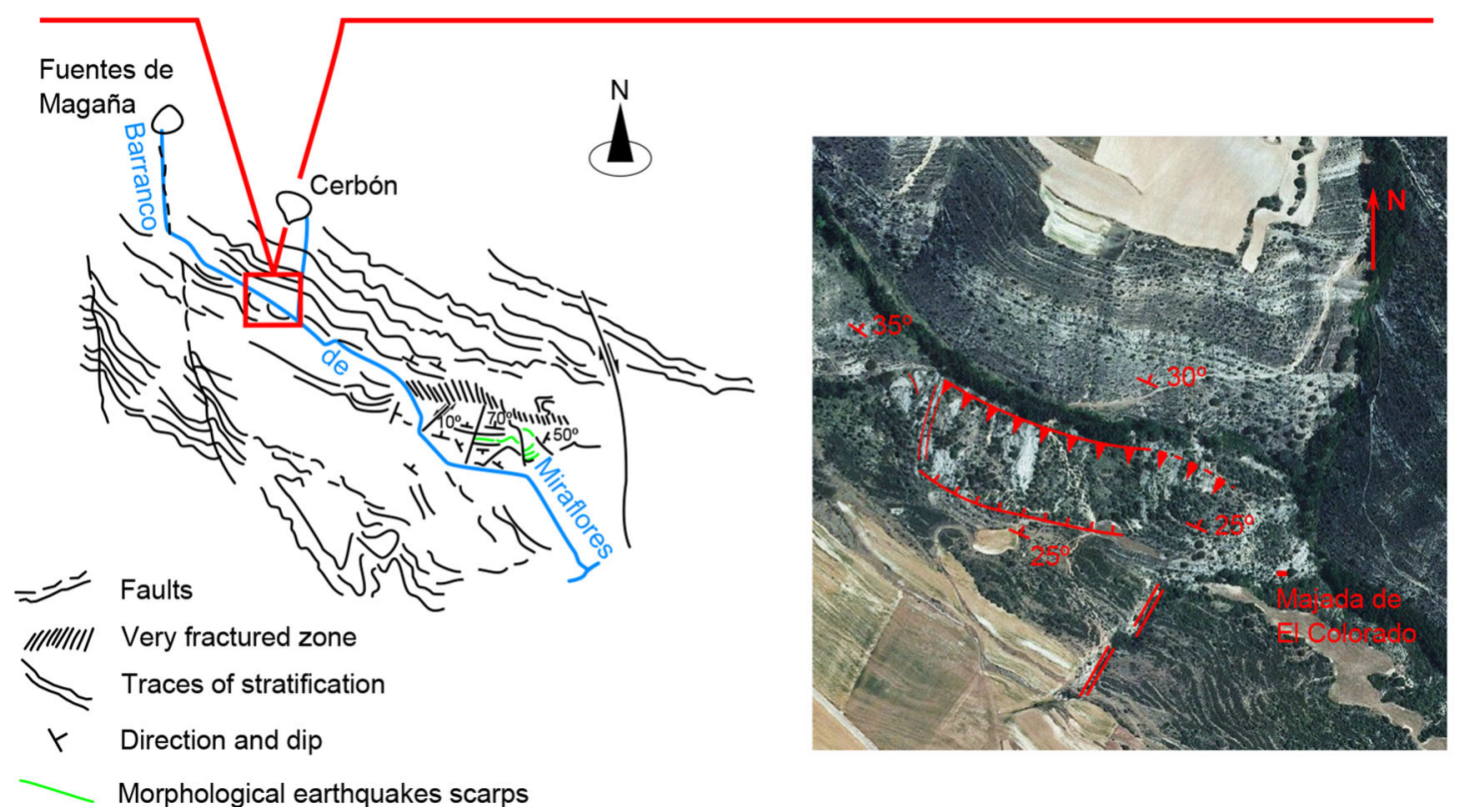

Fig. 8 Geological location and detailed geological map of the induced rocky landslide by 1908 Cerbón earthquake 


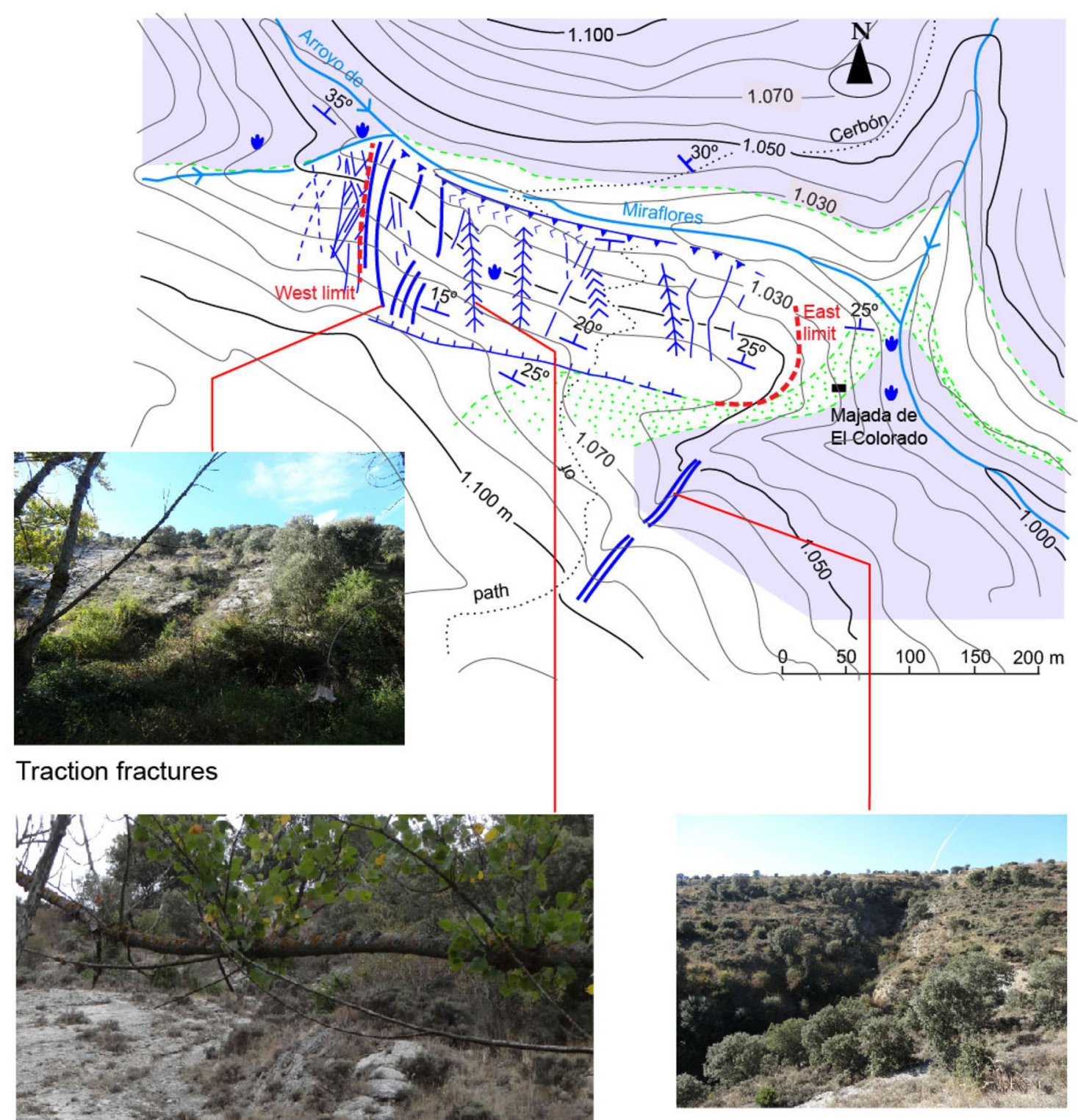

Traction fractures

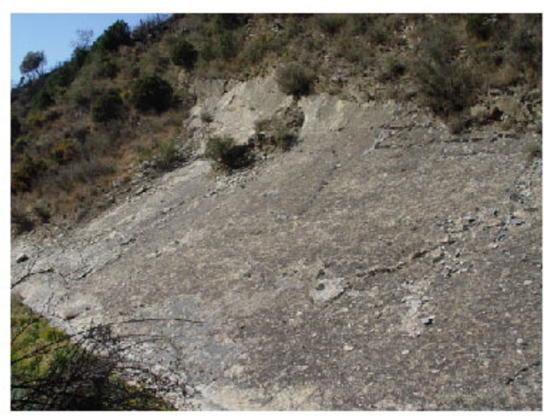

Pressure ridges

Inclined strata near reverse fault

Fig. 9 Ruptures and folds of rocky landslide induced by the 1908 Cerbon earthquake 
slope, except in the E-SE where the relief is elevated as a gentle promontory, on which the ruins of the Majada del Colorado are found. The area resembles a rectangle of some $350 \mathrm{~m}$ in the direction of the strata, by around $200 \mathrm{~m}$ wide, and it has been delimited by fractures that have individualized the block that was displaced by an earthquake (Fig. 9).

The following types of ruptures and structures are distinguished in this zone:

- Open fracture situated on the change of topographical slope that coincides with the first outcrops of the top of the whitish gypsum-marls, strata that have induced the development of cultivated fields in a setting that is essentially rocky. This is the fissure at the crown of the landslide that will be described below. Although it is not continuous, it is at least 300-m long and runs subparallel to the direction of the streambed and the rupture line that lies at the foot of the slope. This fissure forms the southern limit of the rectangle of perturbations that we are defining. Its fracture plane appears to $\operatorname{dip} 90^{\circ}-70^{\circ}$ to the NE; it has displaced the northern, downthrown block by some 3-4 m (Figs. 7, 8, 9). According to the description provided by Naranjo Naranjo (1908), this fissure created a displacement of more than 3 metres in the service road from Cerbón to the fields on this side of the Miraflores ravine, bisecting and laterally displacing it. This head scarp can be seen quite well nowadays, and one can see how a $0.5-0.7 \mathrm{~m}$ band of soil in the fields has been cut along its whole length. According to the descriptions, the head scarp fissure terminates in the E-SE, in a "long, narrow fissure, with other short cracks at both sides and various fine cracks, with a slighting lifting of detritus (...) These fissures interrupt the service road like a fault producing a throw, such as the two sides are not juxtaposed but rather displaced by some two metres." Nevertheless, this morphological trace has changed and the fissures have been infilled, so that it is not easy to identify the elements described by Naranjo (Naranjo 1908).

- Forming the northern edge of the rectangle and on the lower part of the slope, there is a fracture, which has led to the mobilized block slipping over it, rather like being launched from a springboard, leaving quite a wide zone with blocks piled up. In one sector, and associated with this fracture, there is a pressure ridge in the southern upthrown block, where the strata are folded into a small anticlinal fault (pictures in Figs. 7, 9). This fracture plane clearly outcrops for a stretch about $400 \mathrm{~m}$ long, and continues laterally more narrowly until it is lost or hidden beneath the stream debris.

Morphologically, a rocky uplift appears subparallel and very close to the course of the Miraflores stream, which runs in a similar direction to the fissure at the crest of the landslide, but is shorter. This fault scarp has partly collapsed on its northern face, and this has given rise to an elongated pile of broken rocks that have fallen from the scarp. In Naranjo (1908), it is described as a stack of shattered rock covering $500 \mathrm{~km}^{3}$. This scarp is around three to five metres wide, where the stratification is broken, trending NW-SE and dipping $65^{\circ}$ to the south. The southern part of the scarp has been lifted $3 \mathrm{~m}$ above the northern downthrown block. This is the face of the landslip, where, in being pushed northwards, it has dragged and lifted the strata into the vertical and even inverted them, so that they are inclined towards the South. This face has failed along another subvertical fracture that dips towards the South, and which was probably formed during the same seismic action.

Within the block, and trending in the direction of the dip of the strata, two kinds of structure appear:

- In the middle of the rectangle (Figs. 7, 9), three pressure ridges are folded and fractured subparallel to each other, where the strata have been uplifted. They are systematically folded with the same orientation (N30 ${ }^{\circ} \mathrm{E}$ approx.). These ridges are subperpendicular to the open fracture above, and they are crossed by a fracture along the axis of the ridge, as well as by other small fractures perpendicular to the axis (Figs. 7, 9).

- In the western part, three or four fractures have opened up to about $2 \mathrm{~m}$ depth, parallel to the above-mentioned ones (Figs. 7, 9). Naranjo (1908) described them is as follows: to the SW, and along the minor axis of that ellipse, a large crack appeared, which swallowed the debris to a general depth of around $2 \mathrm{~m}$; it left the walls perfectly vertical, separated by $1-2 \mathrm{~m}$ and, at some points, by up to $10 \mathrm{~m}$, with an accompanying crack to the NE. There was another shorter one a short distance away. In the NW, there was another long, rectilinear fissure, divergent from that in the SE, but smaller. Likewise, there is another central fault following the longer middle axis of this ellipse. These fissures are quite easily recognized today.

In the SE part of the landslide, but apart from it, there is a small straight, narrow gully that opens like a trench (Figs. 7, 9), whose morphology does not fit the kind of gully found in this zone and whose origin could perhaps be related to the formation of a fissure arising from this seismic event.

On the slopes of the middle part of the Miraflores gully, 2 $\mathrm{km}$ further to the SE, there is an irregular area no more than 1 $\mathrm{km}^{2}$ in extent, containing a high concentration of fractures, faults and ruptures with different directions; the strata also have opposing orientations and subvertical dips, which are in stark contrast to the monotonous stratigraphic arrangement 
of the zone as a whole (Fig. 9). Some of the ruptures are open, slightly displacing the terrain as a series of small scarps, which affect the thin soils of the hillsides. Though the ground is tectonically altered, the general tone of the relief has not been modified, but the impression is that a seismic event provoked the rupture that affects the recent soils.

\section{Numerical simulation of the landslide induced by Cerbón earthquake}

A two-dimensional (2D) Finite Element model of the main cross-section where the above described induced landslide took place has been performed, using PLAXIS 2D software. Figure 10 shows the considered simplified geometry, taken from the available cartography and site information. The main material is limestone, with the inclusion of an impervious loan stratum, as obtained from the geological analyses previously described. At the toe of the slope, an interface clearly appears; it could be due to a pre-existing fault or to a fracture produced during the earthquake itself, previous to the landslide. The material on the right hand of this interface has been modelled as strong limestone, less deformable than the main material. The interface allows sliding of the materials at both sides of it, with a considered sliding coefficient of 0.2 , because the fracture has a very smooth appearance, according to the research carried out.

All the involved materials are modelled as Mohr-Coulomb type, with standard parameters for each type of material. These parameters are given in Table 2.

As previously mentioned, this earthquake took place in winter, when the water table is expected to by high, but very unlikely to reach the soil surface at the head of the slope. For calculation purposes, its location has been estimated $10 \mathrm{~m}$ below the soil surface on the left boundary, and at the surface on the right one (superficial water table at the valley, see Fig. 11).

First of all, initial stresses under static conditions (only under vertical gravity loading) are calculated considering the water pressure caused by the water table, as previously described. The estimation of horizontal effective stresses has been performed with Jaky's formula, since, even if this is clearly not a horizontal layered soil configuration, it can be considered accurate enough for this estimation. As a conclusion of this first calculation, stability of this slope under static conditions was found.

After that, a pseudo-static approach was done, assuming a rightwards horizontal acceleration. The aim was to obtain the value of this horizontal acceleration triggering the landslide. A maximum target horizontal acceleration of $1 \mathrm{~g}$ is imposed to the program, which, starting from zero, slowly increases this value in several steps, looking for convergence in each one of them. The simulation stops when, in one of these steps, convergence is not achieved after a certain number of iterations. This fact can be interpreted as the slope failure, and the acceleration at which it takes place gives us an idea of the horizontal peak acceleration of this particular earthquake.

Under the above-mentioned conditions, the pseudo-static horizontal acceleration triggering the landslide is estimated as $0.051 \mathrm{~g}$, which would represent a a dynamic peak acceleration of 1.5 times this value, i.e. $1.5 \times 0.051 \mathrm{~g}=0.076 \mathrm{~g}$. This value is not negligible at all, demonstrating a site seismicity level above the minimum threshold established by the current seismic regulations of application in Spain. The obtained failure surface is the one

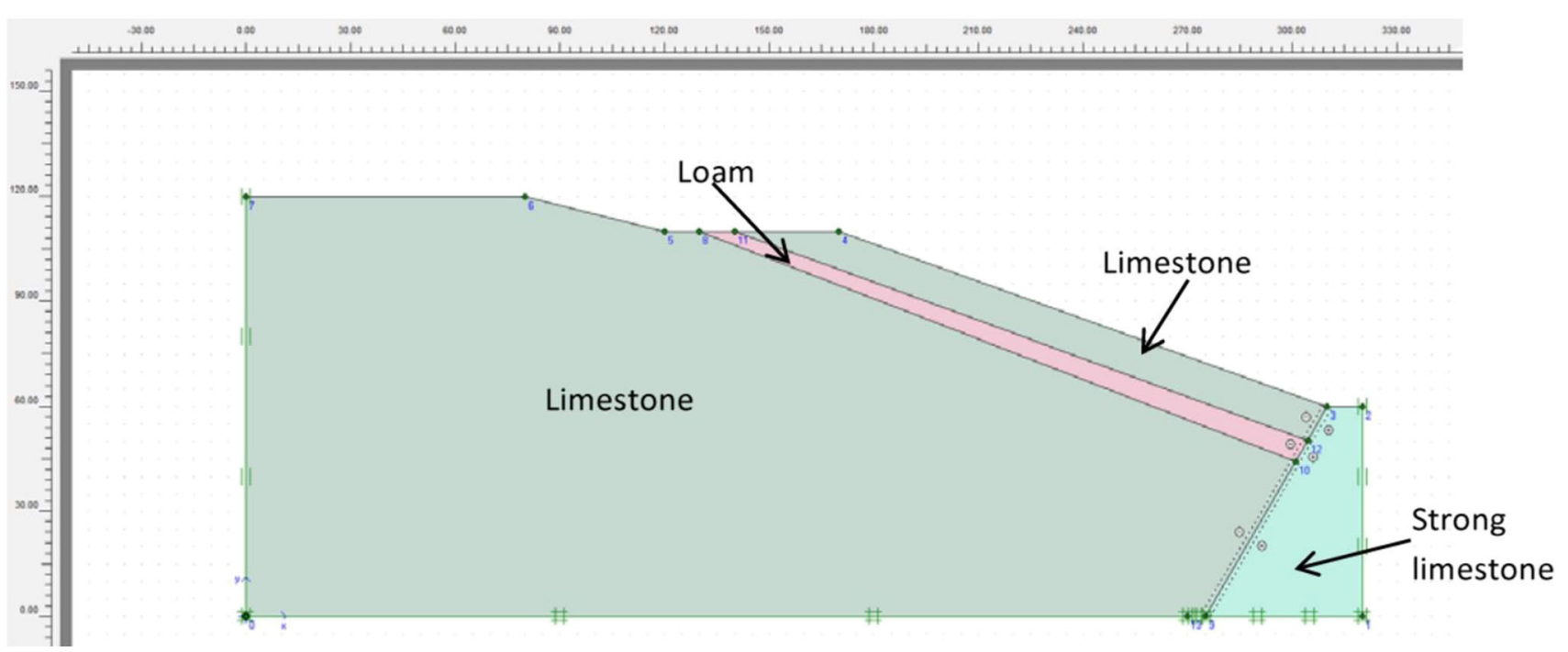

Fig. 10 Simplified cross section considered for the 2D FEM simulation 
Table 2 Parameters for the materials involved in the numerical simulation (Ayala 1987)

\begin{tabular}{llll}
\hline Material & Strong limestone & Limestone & Loam \\
\hline Dry specific weight $\left[\gamma_{\text {dry }}\left(\mathrm{kN} / \mathrm{m}^{3}\right)\right]$ & 20 & 20 & 16 \\
Wet specific weight $\left[\gamma_{\text {wet }}\left(\mathrm{kN} / \mathrm{m}^{3}\right)\right]$ & 25 & 25 & 18 \\
Permeability $[K(\mathrm{~m} / \mathrm{s})]$ & $1.15 \times 10^{-7}$ & $1.15 \times 10^{-7}$ & $1.15 \times 10^{-11}$ \\
Elastic modulus $\left[E\left(\mathrm{kN} / \mathrm{m}^{2}\right)\right]$ & $1.00 \times 10^{6}$ & $1.00 \times 10^{4}$ & $1.06 \times 10^{4}$ \\
Poisson's ratio $(v)$ & 0.3 & 0.3 & 0.2 \\
Cohesion $\left[c\left(\mathrm{kN} / \mathrm{m}^{2}\right)\right]$ & $2.00 \times 10^{4}$ & $2.00 \times 10^{4}$ & 20 \\
Friction angle $\left[\phi\left(^{\circ}\right)\right]$ & 40 & 40 & 15 \\
Dilatancy angle $\left[\psi\left({ }^{\circ}\right)\right]$ & 0 & 0 & 0 \\
\hline
\end{tabular}

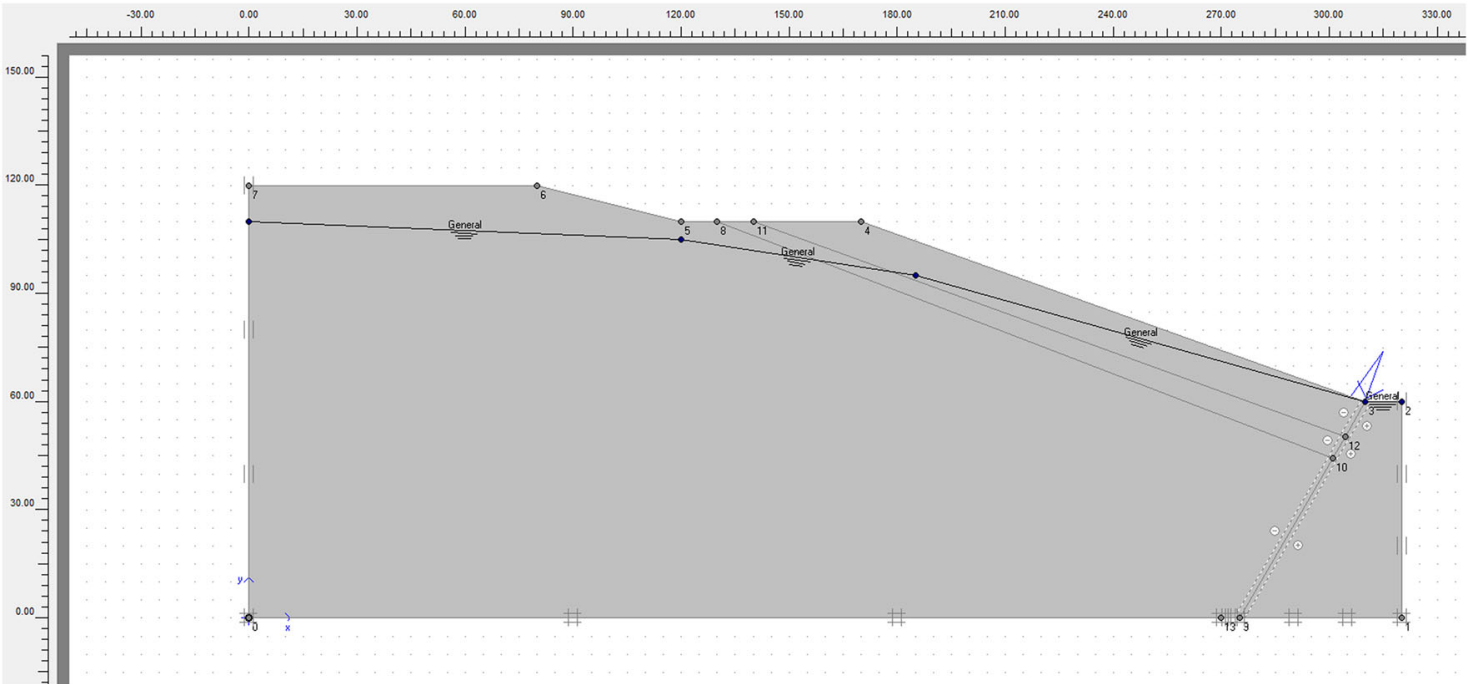

Fig. 11 Estimation of the water table in the numerical simulations (10 $\mathrm{m}$ deep on the left boundary)

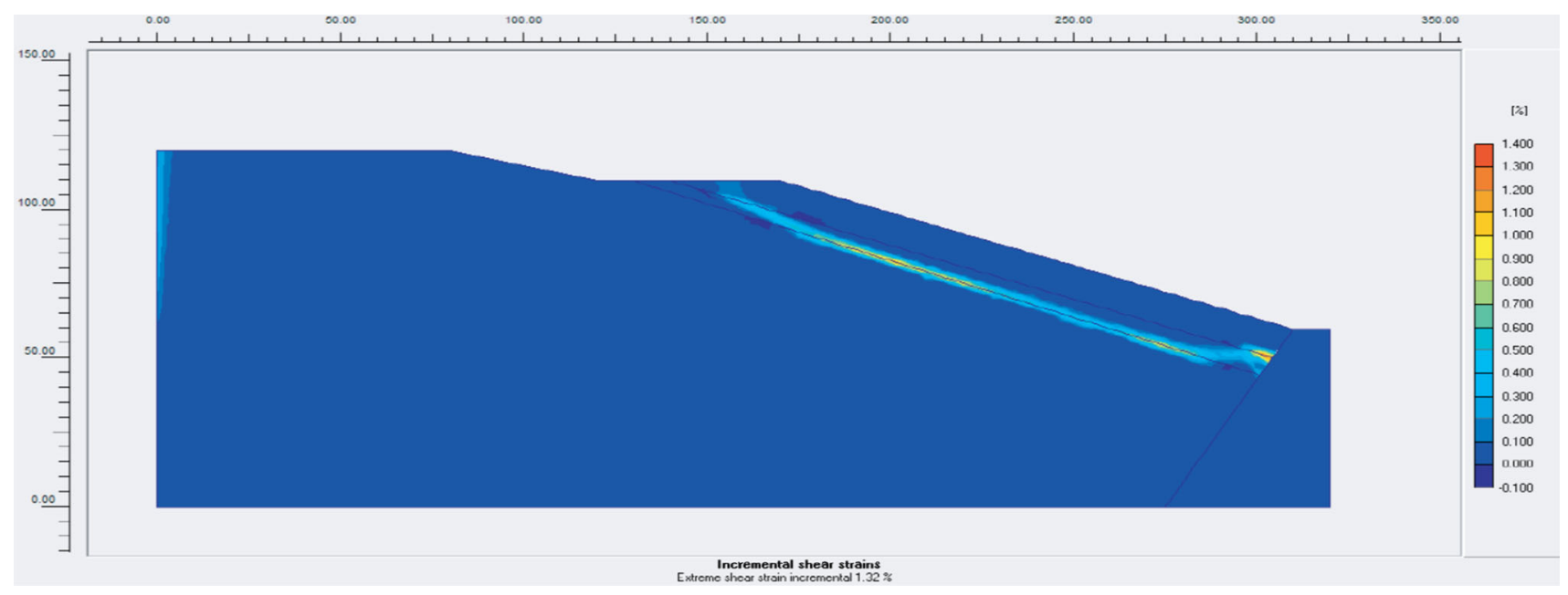

Fig. 12 Sliding surface obtained with the numerical simulation, for a pseudo-static horizontal acceleration of $0.051 \mathrm{~g}$, with the water table as estimated in Fig. 10

depicted in Fig. 12, which fits very well the field observations.

A sensitivity analysis has been also carried out, since the actual water table during the earthquake is unknown.
Working along this path, it was found that, for the water level $15 \mathrm{~m}$ deep on the left boundary $(5 \mathrm{~m}$ deeper than in the previous simulation), the horizontal acceleration would be $0.058 \mathrm{~g}$, while for $20 \mathrm{~m}$, the acceleration would be 0.078 
Fig. 13 Initial geometrical model considered for the 3D simulation. The components of the horizontal acceleration are indicated

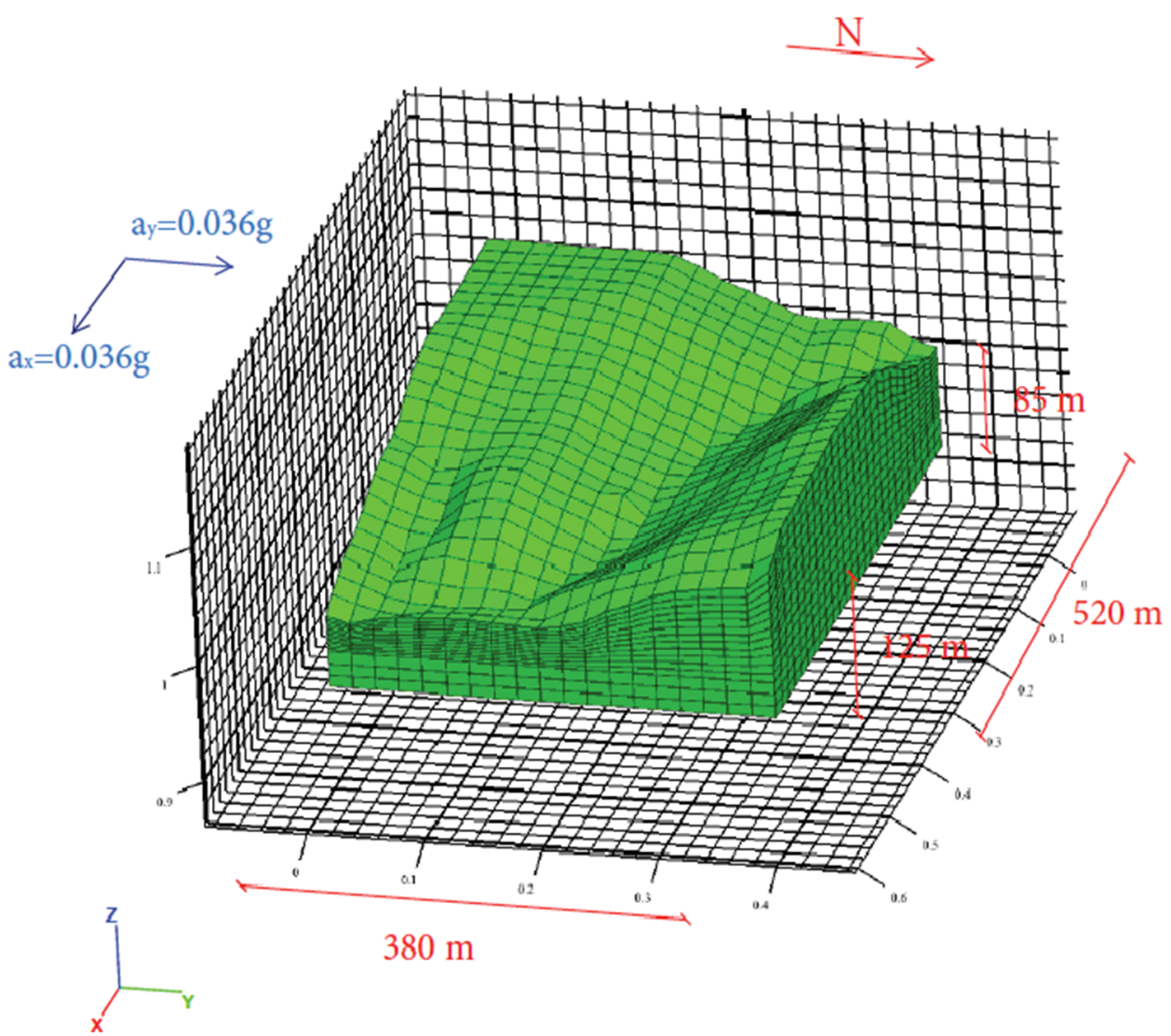

g. In winter season, the water table is not likely to be deeper than that, and hence, we can assess that the horizontal, pseudo-static, triggering acceleration would have a range of $0.051-0.078 \mathrm{~g}$ (peak accelerations in the range of $0.0765-0.1170 \mathrm{~g})$.

The 2D model provides a first estimate of the landslide and allows us to calculate an appropriate value for the seismic design load as it has been explained above. Moreover, since the current actual topography is known, it has also been possible to recreate the original topography before landslide and develop a 3D modelling using FLAC 3D. Figure 13 shows the 3D topography of the area before the landslide that was introduced in the calculation software. This finite differences approach was selected to check if the results found with these different methodologies are in agreement with the previous finite method simulation.

Following the provisions of the $2 \mathrm{D}$ model, the water table has been introduced $10 \mathrm{~m}$ below the soil surface. Using the same properties of the involved materials and considering the pseudo-static seismic load decomposed into the two horizontal components, with the value previously obtained from the $2 \mathrm{D}$ simulation $(0.051 \mathrm{~g})$, a safety factor of 1 was obtained for the calculation, which demonstrates the validity of the $2 \mathrm{D}$ simulations. The results in terms of shear strains are depicted in Fig. 14.

In Addition to this analysis of trying to identify this earthquake by means of its representative horizontal acceleration as previously obtained, it is worth mentioning that there are some other options to characterize an earthquake by means of retrospective back analysis. It is recognized that the capacity of an earthquake to trigger a landslide mainly depends on its magnitude, distance to epicentre and duration. Coherent landslides, like the one dealt with, usually have a significant duration, and therefore, in their study, it is recommended to take into account more than one single history of accelerations in a point. Along with the peak acceleration, it is usually advisable to use energy considerations, such as the Arias intensity (AI) (Arias 1970).

Taking into consideration the Magnitude (5), the distance to the epicentre (less than $10 \mathrm{~km}$ ) and the probable peak acceleration previously calculated $(0.076 \mathrm{~g})$, the AI and induced deformation (Newmark's displacements, ND) can be estimated (Jibson et al. 1998; Jibson and Harp 2000). For a distance to epicentre of $5 \mathrm{~km}$, the $\mathrm{AI}=0.3 \mathrm{~m} /$ $\mathrm{s}$, and $\mathrm{ND}=2 \mathrm{~cm}$; if the distance is $3 \mathrm{~km}, \mathrm{AI}=0.9 \mathrm{~m} / \mathrm{s}$, and ND $=9 \mathrm{~cm}$. 

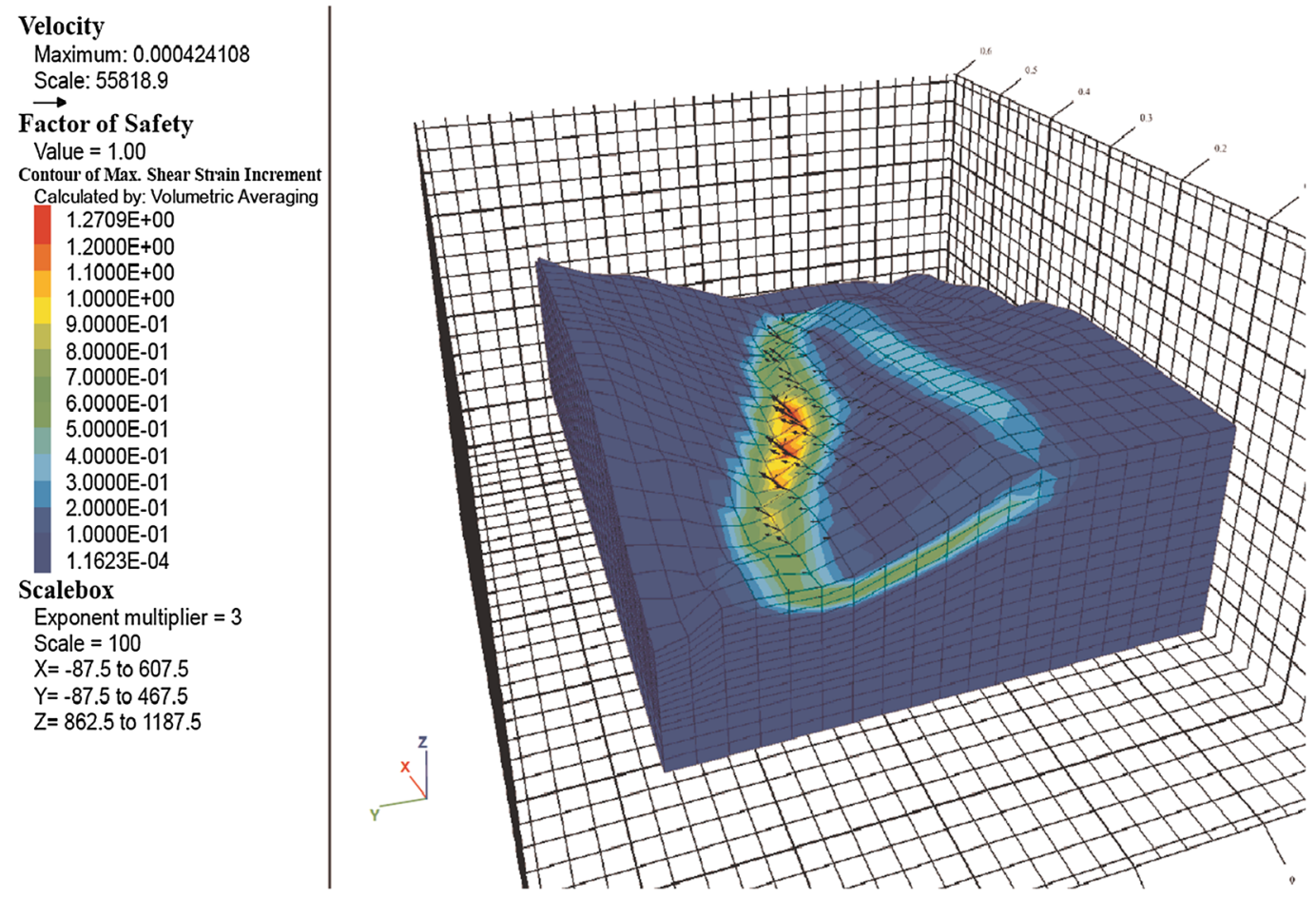

Fig. 14 Sliding surface obtained with the 3D simulation, for a pseudo-static horizontal acceleration of $0.051 \mathrm{~g}$, with the water table $10 \mathrm{~m}$ below the soil surface (as for the 2D simulation)

For admissible displacements, Keefer and Wilson (1989) and Jibson and Keefer (1993) propose $10 \mathrm{~cm}$; thus, cracking and extensive loss of shear strength of the soil can occur if permanent displacements are higher. Following these ideas, for distances to the epicentre smaller than $3 \mathrm{~km}$, displacements higher than this limit might have been expected.

\section{Discussion}

\section{Characteristics of earthquakes in the zone}

In the upper valley of the river Alhama and in a $10 \mathrm{~km}$ radius around Cerbón, small to medium magnitude seismic events occur with certain frequency. Permanent deformations of the rocky substrate have been produced, as well as fissuring and collapse of some dwellings, at least in the following locations: Magaña, Aguilar del Río Alhama, Cerbón, Fuentes de Magaña, Valdeprado and Castillejo de San Pedro. Since it has been happening even for events of magnitude ranging from 2 to 3 for over more than one century, it indicates the seismic risk that certainly exists in the area (and which would need to be taken into account if new dams are to be built, and so on). It is worth noting that most of the towns were abandoned decades ago, and these buildings, with no maintenance, are very vulnerable.
On numerous occasions, alteration of the water regime affects the hydrogen sulphide waters. This phenomenon is not unusual, since the presence of hydrogen sulphide springs and wells is quite frequent in the Wealden facies in this area, due to the oxidation of pyrites or the presence of gypsum with organic matter (Sanz and Yélamos 1994). There are hydrogen sulphide springs near Valdeprado, Ágreda, Cigudosa, Las Fuesas, Castillejo de San Pedro,Magaña, Navajún, Dévanos and Suellacabras.

The explanation of hydrogeochemical anomalies, such as the appearance of new hydrogen sulphide upwellings in Trébago following the Cerbón earthquake, seems to correspond to an increase in the fluid pressure in the compression zone of the fault that generated the earthquake. During this event, semithermal, hydrogen sulphide waters were released from depth. As the new upwellings emerged at a temperature of $28^{\circ} \mathrm{C}$ (bearing in mind that the springs in this area usually flow at 12 or $13{ }^{\circ} \mathrm{C}$ ), if we assume a normal geothermal gradient, this would mean that the water came from a depth of around $500 \mathrm{~m}$. Undoubtedly, these springs did not exist previously, and it would seem that they did not persist for very long time. As described by Naranjo, in Trébago no perennial cold or thermal hydrogen sulphide springs have ever existed, except for a number of seeps in the Dehesa de Magaña, close to the municipality of Trébago. 


\section{Intensity of the Cerbón earthquake}

The majority of seismic events recorded in the Iberian Peninsula have had magnitudes of between 4.8 and $5.0 \mathrm{Mw}$ and peak intensities of VI-VII MSK. In most of the cases, the macroseismic areas cover $80-100 \mathrm{~km}^{2}$, but the relevant geological effects hardly affect more than $10 \mathrm{~km}^{2}$. Likewise, very often the geological effects are related to small local displacements (of unstable areas), block displacement and rock falls (Bullas 2002; La Paca 2005); cracks of millimetric width and decametric length on Quaternary terrains that are poorly compacted, and, most importantly, the previously mentioned hydrological changes in springs and wells.

The collation of data about this historical earthquake, with the revision and interpretation of its side effects based on historical documents, might be enough to assign and use the Environmental Seismic Intensity scale, ESI-2007), aiming to establish the local intensity around the earthquake's epicentre.

According to this scale, this earthquake showed characteristics of intensity IX, including the presence of a rocky landslide and the fissure zone described above, with in excess of $106 \mathrm{~m}^{3}$ of remobilized material. The dimensions of the largest blocks mobilized exceeded $50 \times 50 \times 25 \mathrm{~m}$, while the displacement was less than $10 \mathrm{~m}$, since once they had fallen to the base of the valley they could not go any further.

In terms of the spatial distribution of the instabilities with respect to the epicentre and according to the magnitude of the event, we can refer to the limiting curves proposed by Keefer (1984), or those constructed by Delgado et al. (2011) for Spanish earthquakes. This type of coherent seismo-induced instability does not correspond to low-magnitude seismic events. Rather, allowing that it lays at the very epicentre (or very close to it), it would require an earthquake of magnitude between 4 and almost 6 . The greater part of the coherent-type seismoinduced instability is associated with events of at least VI-VII

There are characteristics of intensity VIII if we consider the appearance of new springs with different physicochemical properties and abnormally high temperatures. On the other hand, the presence of dust in the epicentral area of the Miraflores ravine would develop from the intensity VIII event or greater.

Nevertheless, the destruction of fences together with the landslide (although unaffected by this) and the damage consisting of small cracks and tiles falling from dwellings in Fuentes de Magaña would indicate a Mercalli intensity of no more than VIII.

\section{Seismogenetic sources}

For the reasons listed below, it is difficult to identify the seismogenetic sources in the study area:

1. Low magnitude seismic series (between 2 and 2.4) can be produced by any minor fault, and there is no reason they should outcrop on the ground surface. Moreover, in this part of Spain, where the seismic network is still rather sparse, the error of localization of small events can be several kilometres or even tens of kilometres. Thus, correlation with tectonic structures is difficult.

2. Throughout the Quaternary, erosive processes in this area have been huge. This means there is a lack of significant and extensive recent deposits in the epicentre zone (and in the Valley of the river Alhama in general), that might be deformed by and provide us with evidence of tectonic activity.

However, we can make a number of orientative general comments: in the first place, on a wide regional scale, the distribution of historical and recent seismic events in Sierra de Cameros shows a clear dispersion within a higher density concentrated near the NE borders, linked according to zones with tectonic structures, where the amount of deformation during the Cenozoic component was greater. The type of epicentral distribution and the shallowness of the hypocentres point to the main seismogenetic source in this zone being the Moncayo and Cameros nappe, as well as the faults associated with them. According to the distribution of the seismic events that we are studying, these must be related to a fault in the Alhama valley in the Magaña sector. The location of the aftershocks around the study zone of the Aguilar del Río Alhama earthquake, and the intensity that was experienced in Magaña, leads us to believe that the Cerbón landslide falls fully within the seismic activity of the zone, and we cannot reject the possibility that the landslip was caused by the same seismogenetic source. Of the faults recognized at a local level, the Miraflores ravine stands out as a zone that is intensely tectonized; it lies $2 \mathrm{~km}$ from the landslide and from a N-S trending fault that passes to the east of Magaña and Fuentes de Magaña, but no further data are available. In the surrounding area, where the recent sediment record is preserved $10-15 \mathrm{~km}$ to the south and on the southern edge of the Cameros Basin, there is evidence of Miocene-Quaternary tectonic activity. This supports the hypothesis of recent activity in the zone of the Moncayo nappe. In 2004, there were several small earthquakes measuring less than 3 on the Richter scale, which were felt in Ágreda, San Felices, Matalebreras, Muro de Ágreda, and to a lesser extent in other nearby villages, all lying in the so-called Tierra de Ágreda. As we can see in Fig. 1, three epicentres of the microseismic 
events were located in the Moncayo fault, mentioned above, which runs west from Vozmediano to the Sierra del Madero.

\section{Interpretation of the surface deformations of the 1908 Cerbón earthquake and the rupture mechanism using mathematical simulation.}

The deformations produced in the ground and in the epicentral area of this quake are all very characteristic and suggestive. Accordingly, considering the local geology and topography, the following mechanism of generation of the phenomenon can be proposed: the epicentre of the earthquake must have been very close and to the SE (perhaps associated to the tectonized zone $2 \mathrm{~km}$ away, in the Miraflores ravine). Accompanied by a cloud of dust, the waves propagated from SE to NO, according to contemporary oral testimonies about the direction the noise came from, the way that walls were broken in the Majada del Colorado, and the orthogonal orientation of the pressure and traction structures of the rocky hill in Cerbón. All the rock mass is divided in thin layers with the same direction and dip throughout the epicentral area, which gave rise to a strongly anisotropic environment, wherein the orientation of the stratification, also NW-SE, the supposed presence of a reverse fault with the same direction, which manifested discontinuously along the stream bed, could have contributed to the preferential propagation in this direction. This would explain why the earthquake had more impact in Fuentes de Magaña than in Cerbón, assuming that the epicentre had been very close to the rocky hill in Cerbón. Fuentes de Magaña lies downdip, while Cerbón lies along the strata and is protected from the northern slope of the Miraflores ravine, which is higher than the southern one and which would oppose the propagation of seismic waves. The local geological and topographical conditions around the rocky hill in Cerbón were very significant. In the first place, the route of the Miraflores ravine coincides with the direction of the regional stratification; it fits specifically and closely to particular horizons. The strata dip against the slope on its left bank and they are stable. On the right bank, they dip with the slope. In no instance have they been exposed by the incisive vertical erosion of the river at the foot of the slopes, so that under static conditions, they could not have been moved except with the intervention of a seismic event. There is no other slope so extensive elsewhere in this ravine or in others in the zone that resembles a structural rocky hill like that of Cerbón. This feature means that the effects of the seismic waves could be felt in such a particular way, provoking its destabilization due to the contribution of the clayey detachment layer. There are other slopes further downstream, where it is thought that the earthquake may have also created momentary situations of quasi lack of equilibrium and thrusts, which have left their mark in the form of vertical stratifications at various points in the bed of the ravine on its right bank, but which did not cause a generalized mobilization.

The shallow movement in the unstable rock mass give an explanation to the systematic folding into several ridges and fractures appearing in the rock pavement, in the landslide. The amount of shortening of the anticline folds is approximately compensated by the traction displacement.

As we can see, this movement can be classified as a rock landslide but, thanks to the modest displacement involved, the stratigraphy of the rock was not disrupted as the mass movement progressed. Within the mass, the structure of the seismic waves that generated it were preserved as evidence. Nevertheless, a large amount of energy is required to set in motion a coherent mass of rock, such as this one. The greater part of coherent seismo-induced instability (the coherent typology is less frequent), are associated with events that have an intensity of at least VI-VII. The majority of seismo-induced instabilities in Spain Alfaro et al. (2012) are of disrupted typology (Keefer 1984). These instabilities usually correspond to rockfalls and soilslips, whose structure becomes disorganized as the mass movement progresses. This is why small excitations of M-2.6 can trigger such movements on slopes in strict equilibrium and they are very frequent for low- moderate magnitude events (Mw less than 5.5).

\section{Conclusions}

In this paper, a methodology aiming to improve the seismic knowledge at a given site, where little or no information is available, is presented. This approach has been extensively and successfully employed in the past, and is based on identifying and quantifying scarcely known earthquakes, and includesg historical research, geological field investigation and retrospective numerical simulations on the effects produced by historical earthquakes.

The particular case study analysed in this paper (1908 Cerbón earthquake, Spain), occurred at a site with a low seismic level. This earthquake caused a landslide, identified and inspected in situ, which has been of paramount importance to understand the deformations and ruptures triggered by this particular earthquake. The assumption of the geological parameters of the materials involved in the landslide, as well as the very well conserved landslide characteristics (which have given us the clues on the displacement of the soil and rupture), have been the starting point for a pseudo-static numerical simulation through which the range of possible horizontal peak acceleration triggering this slope instability has been obtained, and thus, the earthquake has been quantitatively identified. The 
mechanism of rupture has also been accurately reproduced. Thus, the most likely values for the peak horizontal acceleration range from 0.051 to $0.078 \mathrm{~g}$, demonstrating the relative importance of this earthquake.

It has also been concluded that the analysed landslide seems to be inside of the epicentral area, located very close, northeast from the epicentre, according to the propagation of the seismic wave. The intensity of this earthquake could be in the range VII-IX, according to ESI2007. Hydrogeological affection and some other landslides and slope instabilities were observed in an area of $50 \mathrm{~km}^{2}$. These effects seem to be very high according to Mercalli's scale, showing a likely superficial mechanism. The 1961 Aguilar del Río Alhama earthquake, in the same site, could have been caused by the same seismic-genetic source, since it was also a shallow earthquake.

In summary, this research demonstrates that this particular earthquake should not be neglected, and must be incorporated in the seismic catalogues for the sake of completeness.

Acknowledgments The authors want to thank all those who have helped us in collecting the information on the 1908 Cerbón earthquake, as well as the 1961 Aguilar del Río Alhama earthquake. Particularly, we want to express our gratitude to the inhabitants of the following towns: Cerbón, Aguilar del Río Alhama, Fuentes de Magaña, Valtajeros, Suellacabras, San Pedro Manrique, Castillejo de San Pedro, Las Fuesas, Navajún, Cigudosa, Matalebreras, Valdemadera, Inestrillas, Muro de Aguas, San Pedro Manrique, Sarnago, Valdenegrillos, Valdelavilla, Matasejún, Trébajo, Castilruiz, San Felices, Añavieja, Ágreda, Vozmediano, Fuentes de Ágreda, Aldehuela de Ágreda, Olvega, Cueva de Ágreda, Beratón, Pobar and Yanguas. We also thank José Manuel Martínez Solares from IGN for the site information he provided to us. The funding received by Dr. Lopez-Querol from the Spanish Ministry of Economy and Competitiveness through the project BIA2012-31678 is also appreciated.

Open Access This article is distributed under the terms of the Creative Commons Attribution 4.0 International License (http://crea tivecommons.org/licenses/by/4.0/), which permits unrestricted use, distribution, and reproduction in any medium, provided you give appropriate credit to the original author(s) and the source, provide a link to the Creative Commons license, and indicate if changes were made.

\section{References}

Alfaro P, Delgado J, García-Tortosa F, Lenti L, López A, LópezCasado C, Martino S (2012) Widespread landslides induced by the Mw 5.1 Lorca, SE Spain, earthquake of 11 May 2011. Eng Geol 137-138:40-52

Arias A (1970) A measure of earthquake intensity. In: Hansen RJ (ed) Seismic design for nuclear power plants. Cambridge, MA

Auque L, Fernández J, Tena J (1988) Las aguas termales de Fitero (Navarra) y Arnedillo (Rioja) (in Spanish). Estud Geol 44:285-292

Ayala F (1987) Manual de Taludes. Instituto Geológico y Minero de España, Spain
Bird J, Bommer J (2004) Earthquake losses due to ground failure. Eng Geol 75(2):147-179

Egozcue y Cía J (1875) Nota acerca de la constitución geognóstica del suelo de Arnedillo y explicación de un accidente, que se supuso volcánico, ocurrido en los días 1 y 2 de abril de 1875, (in Spanish). Boletín de la Comisión del Mapa Geológico de España 2:241-268

Clemente P (2010) Review of the upper jurassic-lower cretaceous stratigraphy in Western Cameros Basin, Northern Spain. Revista de las Sociedad Geológica de España 23(3-4):101-143

Coloma P, Sánchez Navarro J, Martínez Gil F (1966) Procesos geotérmicos causados por la circulación del agua subterránea en el contacto entre la Sierra de Cameros y la Depresión Terciaria del Ebro (in Spanish). Geogaceta 20:749-752

Delgado J, Marques F, Vaz T (2013) Movimientos de ladera inducidos por terremotos en la Península Ibérica (in Spanish). In: Alonso E, Corominas J, Hurlimann M (eds) VIII Simposio Nacional sobre Taludes y Laderas Inestables. Palma de Mallorca, Junio 2013, CIMNE

Delgado J, Peláez J, Tomás R, García-Tortosa F, Alfaro P, LópezCasado C (2011) Seismically-induced landslides in the Betic Cordillera (S Spain). Soil Dyn Earthq Eng 31(9):1203-1211

El Avisador Numantino (1908) Hundimientos de tierras en Cerbón. (in Spanish). El Avisador Numantino

Gil Imaz A (2001) La estructura de la Sierra de Cameros: deformación dúctil y su significado a escala cortical (In Spanish). Instituto de Estudios Riojanos, Spain

INQUA (2013) http://www.eeecatalog.sinanet.apat.it/terremoti/index. php. Accessed in September 2013

Jibson RW, Harp EMJ (2000) A method for producing digital probabilistic seismic landslide hazard maps. Eng Geol $58: 271-289$

Jibson, R (1996) Using landslides for paleoseismic analysis, in Paleoseismology, chap. 8. Academic Press

Jibson R (2009) Using landslides for paleoseismic analysis, in Paleoseismology, 2nd edn. chap. 8. Academic Press

Jibson R, Harp E, Michael J (1998) Using landslides for paleoseismic analysis, in Paleoseismology. US Geological Survey Open-File Report 98

Jibson R, Keefer D (1993) Analysis of the seismic origin of landslides: examples from the new madrid seismic zone. Geol Soc Am Bull 105:521-536

Keefer D (1984) Landslides caused by earthquake. Geol Soc Am Bull Eng Geol 95:406-421

Keefer D, Wilson R (1989) Predicting earthquake-induced landslides, with emphasis on arid and semi-arid environments. Inland Geological Society

Martín-Escorza C (2005) El sismo del 18 de marzo de 1817 en La Rioja (in Spanish). Kalakorikos 10:327-334

Mas R, García A, Salas R, Meléndez A, Alonso A, Aurell M, Bádenas B, Benito M, Carenas B, García-Hidalgo JJG, Segura M (2004) Geologfa de España (In Spanish). In: Vera JA (ed) SGE-IGME, Madrid

Mas R, María I, Arribas J, Alonso A, Arribas M, Lohmann K, González-Acebrón L, Hernán J, Quijada E, Suárez P, Omodeo S (2011) Evolution of an intraplate rift basin: the latest Jurassicearly cretaceous Cameros Basin (Northwest Iberian Ranges, North Spain). In: Post-Meeting Field Trips Guidebook, 28th IAS Meeting Zaragoza, vol 8. Geo-Guías, pp 117-154

Michetti, AEE (1999) Environmental seismic intensity Scale 2007 ESI 2007. In: Vittori E, Guerrieri L (eds) Memorie Descrittive della Carta Geologica d'Italia, LXXIV. Servizio Geologico d'Italia, Dipartimento Difesa del Suolo, APAT, SystemCart Srl, Roma 
Naranjo E (1908) Relación de un fenómeno sfsmico ocurrido en la provincia de Soria (in Spanish). Notas y Comunicaciones del Instituto Geológico y Minero de España 12:297-302

Palacios P (1890) Descripción física, geológica y agrológica de la provincia de Soria. Comisión del Mapa Geológico de España, Spain

Quijada I, Suárez-González P, Benito M, Mas R (2013) New insights on stratigraphy and sedimentology of the Oncala Group (Eastern Cameros Basin): implications for the paleogeographic reconstruction of NE Iberia at Berriasian times. J Iberian Geol 39(2):313-334

Reichert K, Michetti AM, Silva P (2009) Palaeoseismology: historical and prehistorical records of earthquake ground effects for seismic hazard assessment. Soc Geol Lond Spec Publ 316:1-10

Rey Pastor A (1931) El sismo de La Rioja Baja del 18 de febrero de 1929. Boletín de la Sociedad Española de Historia Natural (in Spanish) 31:467-474

Rodríguez C, Bommer J, Chandler R (1999) Earthquake-induced landslide: 1980-1997, soil dynamics and earthquake engineering. Notas y Comunicaciones del Instituto Geológico y Minero de España 18:325-346

Silva P, González-Hernández F, Goy J, Zazo C, Carrasco P (2001) Paleo and historical seismicity in Mallorca (Baleares, Spain): a preliminary approach. Acta Geol Hisp 36(3-4):245-266

Silva PG, Rodríguez-Pascua M, Pérez-López R, Bardaji T, Lario J, Alfaro P, Martínez-Díaz J, Reichert K, Giménez J, Giner J,
Azañón J, Goy J, Zazo C (2008) Catalogación de los efectos geológicos y ambientales de los terremotos en España en la Escala ESI-2007 y su aplicación a los estudios paleosismológicos (in Spanish). Geotemas 6, 1063-1066

Sánchez Lozano R (1894) Descripción física, geológica y minera de la provincia de Logroño. Memoria de la Comisión del Mapa Geológico de España. Comisión del Mapa Geológico de España, Spain

Tischer G (1966) Über die Wealden-Ablagerung und die Tektonik der östlichen Sierra de los Cameros in den nordwestlichen Iberischen Ketten (Spanien). Beih Geol Jahrb 44:123-164

Vaz T, Zêzere J (2011) Lanslide induced by seismic events in Portugal mainland: identification and characterization. Geophys Res Abstracts 13(EGU2011-4802)

Vollmert A, Reicherter K, Silva P, Fernandez-Steeger T (2011) Landslide mapping to analyse earthquake environmental effects (EEE) in Carmona, Spain - relation to the 1504 event. In: 2nd INQUA-IGCP-567 International Workshop on Active Tectonics, Earthquake Geology, Archaeology and Engineering, Corinth

Wasowski J, Keefer D, Lee C (2011) Toward next generation of research on earthquake-induced landslides: current issues and challenges. Eng Geol 122:1-8 